$$
\text { PE-068.02 }
$$

\title{
TPRRITORY OF AIASKA:
}

DEPPARTMENT OF MINES:

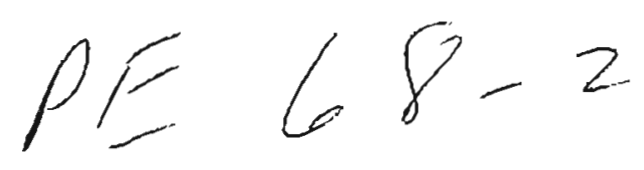

SUPPLIMENTARY RBPORT ON THE XLM COPPER PROSPEOT ON THE $k+6^{8,4}$ MACLAREN GI VER, MT. HAYES QUADRANGLE

by

Robert H. Seund ere

Lisociate Mining Engineor 
The Ka copper prospect is described in U. S. Geological Survey GHrcular 332, THE KATHLFHAMARGRDET (KM) COPPIF PHOSPECT ON THE UYPER MACLAREA BIVER, AISSEA, a report prepared jointly by the U. S. Geologtcal Survey and the Territorial Department of Mines from informetion obtalned during an exarnination of the prospect In August, 1953. In 1954, Alaska Gopper Mines, Inc. acquired the prospect under a lease and option agreement. After two yeara: of exploration, Alaska Copper Nines, Inc. roleas the properfy to the owmers in 1956. Apperently the prospect was released bocause of business eircunstances unrelated to the results of the exploratory work.

In the fall of 1956, the Maclaren River Copper Corporation wes formed to acqulre the KLM prospect and to continue or supplement the exploratory woric done by aska Copper Mines, Inc. In Novobber, 1956, I vist ted the prospect with Farl H. Beistine and Fred S. Pettyjohn, Jr, both merbers of the board of directors of the Maclaren Rlver Oopper Corporation. This report is written to provide up-to-date information for the Department of Mines f1les. A. carp has been built near the tefainus of the glacler on the rest alde of the floodilain of the Maclaren River. An alrstrip suitable for use by multi-engine aircraft has been built on the floodplain about one mile from the camp. There Is a road from the airstrlp to the camp and a ploneer road from the camp to the portel of the underground workings. The camp butldings include two 6-man burkhouses, a mess-hall whth a shower 
and oook's quarters, and a large, unt nsulo,ted, frarne bullding for uae as a repair shdp.

4. shed at the portel to the underground workingd houses a compressor, a worl space for undor repairs, the mil ne track from the portal to the dump, and a storage space for miocellaneous underground equiprent. The mining equipment on the proporty Includes a compreasor, a loader, a two-drill jumbo, and an airpowered diamond drill.

During the time that Alaska Copper Minea, Inc. controlled the property, about 800 feet of underground workings vere drtven, and ebout 1400 feet of exploratory drilling was done. The worklngs and drill holos are shown on BIg. 1. The assay resulto of drill hole samples taken by Alaska Copper Mines, Inc. are shown in Table I, and a description of the drill holes is given IA WORK PROGRESS, ALASKA COPYRR MINES, INC; 1955 WORKING SRASON.

During the examination in November, 1956, the geology exposed. in the underground world nEs was sketched as shour on IIE. 1 . Seven samples were taken; the locations from which the samples were taken shown on $F 1 g .1$, and the renults of the assays are shown in Table II.

The veln material exposed in the end of the first cross-cut appears to be too low-grade to be minable. The voin material exposed near the mouth of the second crose-cut also appears to be too low-grade to be minable, howevor, it was reported that ore from this exposure was used for making a mill teat and that 
It contelned about 3 per cent copper. The discovery outcrop and the holes orilled at the nouth of the firgt cross-cut indtcate that there is an ore-shoot south of the first cross-cut that extenda from the surface down to the diamond arill hole Interaetions about 70 feet below the adit.

The uaderground worldings planned by the Maclaren River Copper Corporation are show on Fig. 2 and in pencll ines on F1g. 1. A drift 1s to be turmed off the first cross-cut to follow the vein gouthward 160 feet. A rai 80 is to be driven from the drift to the surface through the place where percussion drill hole samples 3 and 4 were taken. A whac is to be sunk 120 feet through the place where diand arlil holo amples 20 and 11 wore taken. Drifts are to be driven from the winge at the 50-ft level and at the 100-ft level; 150 feet of drifting is plannod at each level. The proposed exploration program should deternine whether or not there is an ore-shoot under the outcrop. If there is such an ore-shoot, further exploration probably wil be necessary before mining and milling can begin. 


\begin{abstract}
TERRITORY OF ALASKA
DEPARTMENT OF MINES

COLLEGE. ALASKA

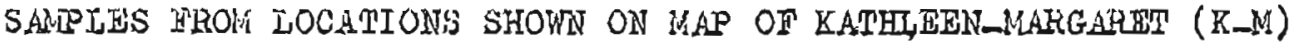
COPPER MINE
\end{abstract}

$\begin{array}{cc}\text { Sample Mamber } & \text { Per Cent Copper } \\ 1 & 7.35 \\ 2 & 3.5 \\ 3 & 6.20 \\ 4 & 4.62 \\ 5 & 2.20 \\ 6 & 6.44 \\ 7 & 3.67 \\ 8 & 5.08 \\ 9 & 2.44 \\ 10 & 6.81 \\ 11 & 4.17 \\ 12 & 7.7 \\ 13 & 2.20 \\ 14 & 4.74 \\ 15 & 2.06\end{array}$

TABLEI

DRIIL HOLE SAMPLIS 
SAMPLES TAKIIN IN NOVEMBHR, 1966.

\begin{tabular}{|c|c|c|c|c|}
\hline \multirow{2}{*}{ Santale No. } & \multirow[t]{2}{*}{ Lergath } & \multicolumn{2}{|c|}{ Ounces per Ton } & \multirow{2}{*}{$\frac{\text { Per Cont }}{\text { Copper }}$} \\
\hline & & coold & Silver & \\
\hline 52 & $10 \mathrm{ft}$ & 0.02 & 0.72 & 4.07 \\
\hline 53 & 10 & $\mathbb{T r}$ & 0.18 & 0.44 \\
\hline 54 & 5 & 0.01 & 0.12 & 0.11 \\
\hline EE & E & $\operatorname{Tr}$ & Ts & 0.11 \\
\hline 56 & 0.2 & 0.02 & $N 11$ & 0.88 \\
\hline 57 & 3.5 & Tr & Tr & 0.33 \\
\hline 58 & 2 & $\mathrm{Nil}$ & $\mathbb{N 1 1}$ & 0.08 \\
\hline
\end{tabular}




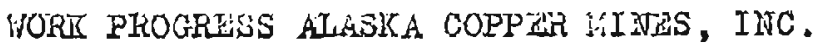
1955 WORKING SEASON

June 1 - - October 15, 1955

\section{IOMGHOL PRRCUSSION DRILLIIG}

Sta. No. 2 (Ist Crosscut)

Hole No. 1. Bearine $S 55^{\circ}$ pisus $18^{\circ}$ drilled $88^{r}$.

Hole No. 2. Bearing $543^{\circ}$ E plus $18^{\circ}$ arilled $64^{\prime}$.

Hole No. 3. Bearing $S 35^{\circ}$ I plus $11^{\circ}$ drilled $76^{\circ}$.

Hole No. 4. Bearing $S 25^{\circ} \mathrm{E}$ olus $15^{\circ}$ drilled $75^{\prime}$.

Hole No. 5. Bearing $522^{\circ}$ E plus $13^{\circ}$ drilled $70^{\prime}$.

Good copper minerals (bornte and chalcopyrite) in quartz vein $8 '$ to 14 ' thick noted in holes Nos. 2, 2 , and 3. Fair coppor content found in wall rock $10^{\prime}$ to $15^{\prime}$ from west contect with quartz. Holes 4 and 5 are in ground too badly broken to allow further progreas. These holos were ebandoned prior to crosscutting veln extengion.

Sta. No. 3 (and Crosscut)

gastrall Hole No. I. Bearlug IN $89^{\circ}$ I plus $13^{\circ}$ drilled $24^{\prime}$. Eastwall Hole No. 2. Bearlng $S 56^{\circ}$ d plus $12^{\circ}$ cirllled $56^{\prime}$. Hastwall Fole No. 3. Boaring 5 290 E plus $29^{\circ}$ drillod $48^{\prime}$. Roof Hole No. 1. Bearing $4^{\circ}$ if plus $42^{\circ}$ arilled $40^{\prime}$. Roof Hole No. 2. Beering $\$ 75^{\circ}$ " plus $42^{\circ}$ ärillea $48^{\prime}$. Hestwall Hole lio. 1. Bearing in $83^{\circ} \mathrm{W}$ plus $12^{\circ}$ drilled $16^{\prime}$. Hestwall Fole No. 2. Bearine $580^{\circ}$ w plus $33^{\circ}$ dxilled $48^{r}$. Na. 2 Crosecut Howe (Ait face) Bearine $N 75^{\circ}$ E plu. $20^{\circ}$ drilled $88^{\circ}$.

Good copper minerals (bornite, chalcopgrite, and chalcocite) in quertz vein which eppears badly shattered due to faulting noted in $\$$ holes Nos. 2 and 3 . No mineral in hoj.e No. 1 which mat have been started too far north to crosscut vein. Good copoer ulneralization noted in both roof holes. No copper mineral Pound in west side holes. The character of the rain vein changeg at this point on its strike. Where 
the vein held to a solid $10^{\prime}$ to $15^{\circ}$ op thickness at crosscut points south of Station No. 3, It now appears split into several smaller veins seperated by narrow bands of altered greenstone. An east-west fault exposed by ths iêstwall hole No. 1 razy bo the cause of this chenge in character.

TOTHL LONGEOJE PERCUSSION DRILJING 731 Feet.

\section{DIAMOND DRILE PROGRESS}

Sta. No. 2 (Ist Crosgcut)

Hole No. 1. Bearing $S 50^{\circ}$ In mus $45^{\circ}$ drilled 118'。

Hole No. 2. Bearing $S 36^{\circ}$ En minug $45^{\circ}$ drilled 130'.

Good coppez mineral (chalcopyrite, some bornito) crosacut at a point approximately 70' below drift level. Al ao a definite change in wall rock on east side of vein noted by core study. The predominance of chalcopyrite over bounite and the change of wallrocir from greenstone to a dolomite alteration product are the majox changes noted by thls deeper drilling. Vein and mineralized west wallrock are aporoximately the some as that crosecut in flat drill holes abore.

Hole 2 SO. $^{3}$ at Sta No. 4 Bearing $575^{\circ} \mathrm{I}$ minus $3^{\circ}$ driller $83^{\circ}$.

Hole No. 4. $20^{\text {t }}$ of Sta. No. 5 Bearing S $75^{\circ}$ in minuo $4^{\circ}$ drilled $33^{\prime}$.

Hale No. 5. 22' N of sta. No. 5 Bearing in $25^{\circ}$ "plus $5^{\circ}$ arllied $31^{\prime}$.

Hole No. 6. at Sta. No. 4 Bearing " plus $5^{0}$ Brilled 18

Hole No. 7. at Sta. No. 4 Bearing $N 80^{\circ}$ eminus $45^{\circ}$ drillea $76^{1}$.

Hole No. 8. 201 N of Sta. No. 6 Bearing $\mathbb{N} 85^{\circ}$ in minus $45^{\circ}$ arilled $21^{r}$.

No copper mineralg of commercial value found in holes Nos. $3,4,5$, or 6 . Good showing in hole No. 7 at $39^{\prime}-42^{\prime}$, poor $42^{\prime}-46^{\prime}$, and falr $46^{\prime}$ to $53^{\prime}$. Most velue was in form of bornite in altered dolonite in the $46^{\prime}$ to $53^{\prime}$ aroa. Hole Wo. 8 was not completed, however, the indications so far are good and drilling should continue from this point next season.

$$
\text { TOTAL DIAMOND DRIILIIVG } 676 \text { Feot. }
$$


Core recovery was considered poor due ma1nly to eractured rock and ground water. However, sludge ws recovered and used when necessary for assay and study. The results of this drilling prove a grod body of ore in the area srilled with the axcoption of the flat hols dirliled north of Sta. No. 3. The Diamond Drill holes Nos. 3, 4, and longhole No. 2 - face of No.2 Crosscut, al though barren, were important in egtablishing the position of the main rein north of the feulted area at S.ta. No. 3. These holes also confirm the fact suspected last season by crosscut No. 3, that the drift penetrated a barren horizon in the quartz vein starting a few feet north of Sta. No. 3. With down hole No. 7 at Sta. No. 4 (and possibiv No. 8), ore has developed bebow the drift elevation and with surface open cuts Nos. 2, 3, and 5, ore was pound ebove the drift elevation. sin ore body approximately 10 ' thick everazing 6 per cent copper has been blocked out by drflling at Sta. No. 2. 


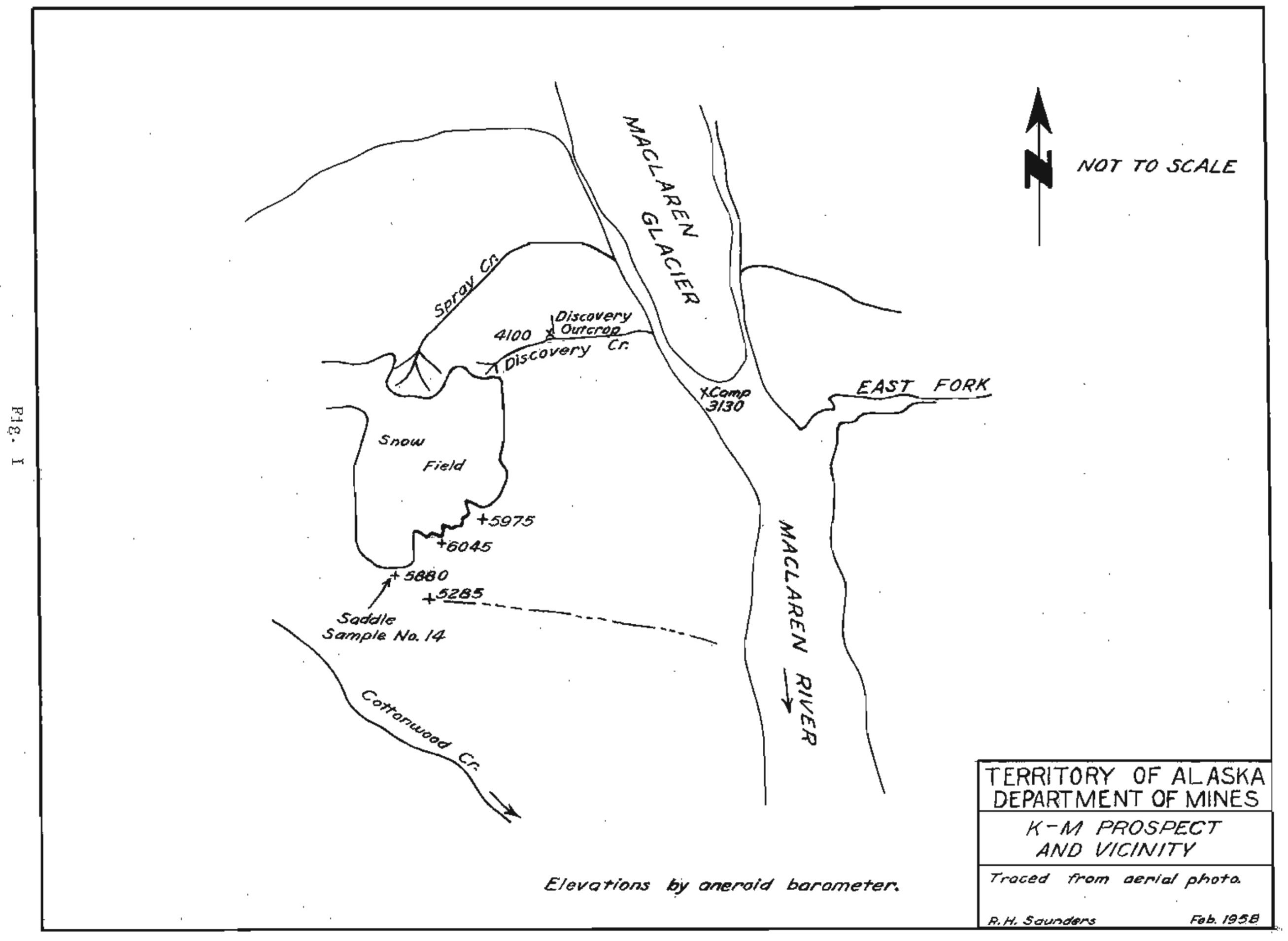




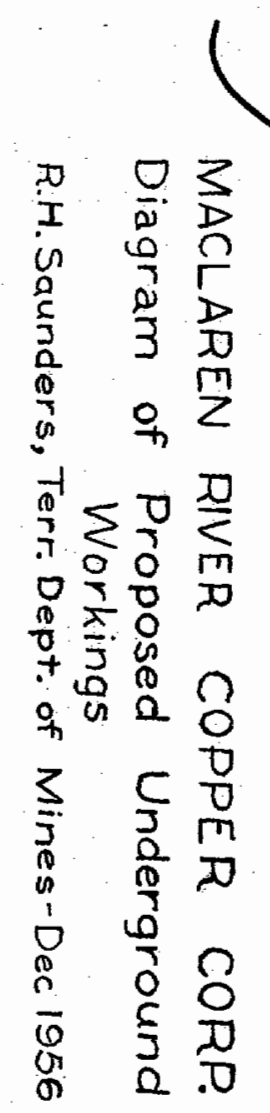

Discovery Creek 


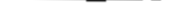

Wages and salaries

Mining contract costs

Equipment rental

Mising supplies purchased

Travel expense

Freight

Cormissary supplies purchased, net

of exrployees' payments

Automotive expense

ilaintenance and repairs

Expeciting expense

Printing expense

Taxes and license

Professional services

Road brjilding expense

office and miscellaneous expense

Depreciation provision

Operating expense

Total expense

Less estimated market value of

$$
\text { ore produced }
$$

Development cost for year
19720.05

14719.29

7354.05

604.77

500.00

1501.07

1274.75

238.56

1000.00

1000.00

825.38

1387.40

67877.31

5597.7

73475.05

48000.00

$\$ 25475.05$
Mr. F. S. Pettyjohn, President

Macliaren River Cokper Corporation
Fairbanks, Alaska

Dear irir. Pettyjohn:

The annexed balance sheet as at 0ctober 31, 1957 and the statement of development costs for the year then ended, were prepared us is from the records of the Vaclaren River Copper Corforation after making such adjustments as

We posted the general ledger from the subsiciary records maintained by your office, but made no attertupt to experith exception the bark statente

Because of the limited nature of our engacement we did not apply customary auditing procedures and, therefore, ments as a wholo.

Yours very troly,

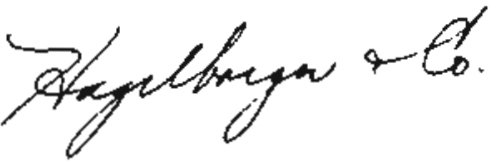

PREFAFED WLTHOUT ATDIT

PAS:dy 
WACLLREN RIVER COPPER CORPORATION

ASSETS:

current:

Cash on hand and in barks

Acoount recoivable, Alaska Freight Lines

Prepaid expenses

Inventory of copper ore, at estimated

market value, partialiy pledsed contra

Supplies inventories:

Mining supplies

$\$ 750.00$

Comrissary supplies$$
3600.00
$$

Total current assets

Mining properties, buildings and equipment, at pax value of stock issued therefor,

with subsequent addions at cost,

partially plodged as security on

note paykble

Iess depreciation reserve

3195938.14

Development costs, statement annexed

190340.40

25475.05

Deposits and organization expense
BALAIICE SHEET, October 31, 1957

LIABILITIES:

Current:

Accounts payable, trade

secured by a portion of equizment

Account payable, Burgess Construction $C 0$.

Accrued tares and withholdings

Accrued wages payable

Account payable, officer

Accrued liabilities on contracts

Total current liabilities

793148.13

Long-term obligation to Defense winerals
Exploration Administcation, payable by $5 \%$ of smelter returns for seven years

$\$ 13073.20$

18000.00

8411.67

1201.64

1950.00

1959.92

2974.29

47570.72

27000.00

CAFITAL

Capital stock:

Au thorized 1,000,000 shares, \$1.00

par value per share, issued and
outstanding 221,009 shares

215815.45

$\underline{221009.00}$

2295579.72

295579.72

PREFARED WLTHOOT AUDIT 
Mr. F. S. Pettyjoin, Jr.

President

MacLaren River Copper Corporation

Box 981

Anchorage, Alaska

Dear Mr. Pettyjohn:

The following is a report of sampling and assaying recently completed by the undersigned at the $K-M$ Copper Mine, which includes a report of Diamond Drill Hole No. 17 and the results of that drilling.

\section{First}

The ore sampled was the main ore body exposed by the exploration drift driven by the MacLaren River Copper Corporation. The ore body extends south from the intersecting crosscut fifty seven feet to a feult where the vein disappears. Eleven channel samples were taken at regular five foot intervals beginning at the intersecting crosscut and continuing south fifty feet toward the fault. The vein was inaccessable for theseven feet adjacent to the fault because of timber. The sample locations are as shown on my map of the K-M Copper Mine. The sample and assay data for these samples is as follows:

Sample No. Sample Widths Copper of Goldoz/ton Silver oz/ton

$\begin{array}{lllll}\text { OS-1 } & 8.08 & 1.21 & 0.01 & 0.19 \\ \text { OS-2 } & 8.0 \% & 0.72 & \mathrm{Tr} . & 0.08 \\ \text { OS-3 } & 8.4 & 0.58 & \mathrm{Tr} . & 0.10 \\ \text { OS-4 } & 7.08 & 0.86 & \mathrm{Ni} & 0.10 \\ \text { OS-5 } & 7.6 & 2.19 & 0.01 & 0.34 \\ \text { OS-6. } & 7.08 & 0.63 & 0.01 & 0.08 \\ \text { OS-7 } & 7.09 & 2.53 & \mathrm{Tr} . & 0.28 \\ \text { OS-8 } & 8.69 & 3.88 & 0.02 & 0.40 \\ \text { OS-9 } & 8.09 & 7.19 & 0.04 & 0.40 \\ \text { OS-10 } & 9.61 & 4.09 & 0.27 & 0.50 \\ \text { OS-11 } & 10.59 & 4.46 & 0.16 & 0.44\end{array}$

Averaging the samples shows the ore body to be 8.2 feet wide and to contain 2.71 per cent copper, $0.06 \mathrm{oz} /$ ton gold, and $0.28 \mathrm{oz} /$ ton silver. The increasing values toward the fault shows a shoot of high grade ore. Eliminating 20 feet of low grade, samples OS-1 through OS-4, gives a 37 foot oreshoot averaging 8.3 feet wide and containing 3.70 per cent copper, $0.08 \mathrm{oz} /$ ton gold, and $0.36 \mathrm{oz} /$ ton silver. Again, eliminating 10 feet more of low grade, samples OS-5 and OS-6, give a 27 foot oreshoot averaging 8.7 . feet wide and containing 4.46 per cent copper, $0.11 \mathrm{oz} /$ ton gold, and $0.41 \mathrm{0z} /$ ton silver. Assuming a 4 per cent breaking point, the sampling shows about a 30 foot shoot of mineable ore. 
In addition to the eleven channel samples taken from the main ore body, I took three other semples. The locations of these samples are show on my map of the K-M Copper Mine, and the assay results are as follows:

\begin{tabular}{cccc} 
Sample No & Copper $\%$ & Gold ou/ton & Silver oz/ton \\
\cline { 2 - 2 } & 0.52 & 0.18 & $\operatorname{Tr}$. \\
OS-13 & 0.14 & $T r$. & 0.10 \\
OS-14 & 0.43 & $T r$. & 0.60
\end{tabular}

Second

Diamond Drill Hole No. 17 , azimuth $103^{\circ}$ and inclination $-60^{\circ}$, reached a. length of 252 feet in early December after passing completely through the vein, thus completing the hole: Because this hole is the first long diamond drill hole drilled by the company, the hole was cored for its entire length to learn the exact character of the country rock and to assure the presence of only one vein. The drill hole traversed country rock from O to $173^{\circ}$ passing through large fault from $132^{\circ}$ to $142^{\circ}$. At $173^{\circ}$ the hole entered the copper bearing quartz vein, continuing in vein material to $200^{\circ}$; from $200^{\circ}$ to $211^{\prime}$ the drill was in country rock; vein material from $211^{9}$ to $213^{\circ}$; country rock from $213^{9}$ to $217^{\prime}$; vein material from $217^{\circ}$ to $219^{\circ}$; and country rock from $219^{\circ}$ to $252^{\circ}$.

The geometrical aspects of the vein and fault in the drift, the vein and fault intersected by the drill hole, and the drill hole itself, lead me to believe that the vein intersected by the drill is the continuation. boyond the fault, of the vein exposed in the drift.

The cores from this hole show some geological information which may be of interest. The country rock drilled is a composite of slate, sandstone, and Iimestono sediments.

Comparing these cores with the rock types mapped by Moffit (1912, Plate II) indicates the K-M Copper line is located in a band of east-west irending slate, sandstone, and limestone sediments which are bounded on the north by quartz diorite intrusives and on the south by anygdaloidail diabasic and basaltic lava flows. The quartz diorite of intrusions of the Maclaren can be correlated with the quartz diorite intrusions of the Talkeetna Mountains and part of the Alaska Range - Moffit (1912, page 35) and Moffit (1954, pages 173-175). According to Moffit (1954, page 189) the intmusion of vast quantities of igneous rock during the late Mesazoic was accompanied by the ore deposition. The gold deposits of the Nabesna Mine and the copper-molybdenim deposits of the Orange Hill Mine are contact-metamorphic deposits formed where the quarti-dioxite contacts limestone, Moffit (1954, page 189). Moffit (1912, page 55) states the source of the gold in Valdec Creek to be weathered quartz diorite.

Moffit (1912, pages 29-38) correlates the lava flows of the Haclaren River Region with the Nikolai Greenstone of the Chitina Valley. The source of the copper of the Nizina District (the Kennecott decosits) is believed to be the Nikolai Greenstone, Miller (1946, fage 98). According to Miller (1946, page 100), no ore was found in the greenstone, but 
hot meteoric water leached the copper out of the greenstone to form large rich replacement deposits in limestone. Comparing the K-M Copper Mine with other mines of eastern Alaska, it can be easily seen that with the mine located in a zone of sediments containing limestone and having a quartz diorite-limestone contact to the north and a Nikolai greenstone limestone contact to the south, the geology, is definitely favorable for a large high grade copper-gold deposit.

The cores and sludges from Diamond Drill Hole No. 17, representing the vein and country rock immediately adjacent to each side of the vein only were assayed. For the assay, the cores were taken in five-foot lengths to detemine the digtribution of the copper minerals and gold within the vein. The assays follows:

\begin{tabular}{|c|c|c|c|c|c|}
\hline $\begin{array}{l}\text { Sample } \\
\text { Depth }\end{array}$ & $\begin{array}{l}\text { Core or } \\
\text { Sludge }\end{array}$ & Material & Copper \% & Gold oz/ton & Silver oz/ton \\
\hline $157^{\circ}-169^{\circ}$ & Core & Country Rock & Tr. & NiI & $\mathrm{Nil}$ \\
\hline $173^{\prime}-178 t$ & Core & Vein & 5.30 & 0.17 & $\operatorname{Tr}$. \\
\hline $178^{\circ}-183^{\circ}$ & Core & Vein & 10.14 & 0.04 & 0.58 \\
\hline $183^{\circ}-188^{\circ}$ & Core & Vein & 2.10 & 0.05 & NiI \\
\hline $188^{\circ}-193^{\circ}$ & Core & Vein & 1.70 & NiI & $\mathrm{NiI}$ \\
\hline $193^{\circ}-198^{\prime}$ & Core & Vein & 2.18 & $\mathrm{NiI}$ & $\mathrm{NiI}$ \\
\hline $198^{\circ}-200^{\circ}$ & Core & Vein & $\mathrm{Nil}$ & $\mathrm{NiI}$ & $\mathrm{NiI}$ \\
\hline $211 \cdot-213^{\circ}$ & Core & Vein & 0.07 & Tr. & $\mathrm{Nil}$ \\
\hline $217 \cdot-219$ & Core & Vein & 1.21 & 0.02 & $\mathrm{NiI}$ \\
\hline $225^{\circ}-228^{\prime}$ & Core & Country Rock & 1.24 & $\mathrm{NiI}$ & $\mathrm{NiI}$ \\
\hline $228^{p}-252^{p}$ & Core & Couniry Rock & NiI & $\mathrm{Nil}$ & Nil \\
\hline $169^{\circ}-173^{\prime}$ & Sludge & Country Rock & 2.13 & 0.02 & Mil \\
\hline $1739-1989$ & Sludge & Vein & 4.81 & 0.04 & $\operatorname{Tr}$ \\
\hline $198^{\circ}-202^{\prime}$ & sludge & Country Rock. & 1.01 & Tr。 & $\mathrm{Nil}$ \\
\hline
\end{tabular}

The recovered cores show that the drill hole passed through vein material for 46 feet. Since the inclination of the hole was $-60^{\circ}$, the vein vertical, and the drill hole intersected the vein at about right angles, the -actual horizontal distance represented by the 46 feet is about 23 feet of vein width. From 213 feet to 217 feet, and from 219 feet to 225

feet, is not vein material, but country rock. The two quartz stringers, 211 feet to 213 feet and 217 feet to 219 feet, are too low grade to be considered ore. The vein of actual mineable ore extends from 173 feet to 198 feet in the drill hole, or a vein width of 12.5 feet. The barren quartz, 198 feet to 200 feet, would not be mined.

The average core assay for the vein repregented from 173 feet to 19,8 feet is 4.28 per cent coppor and 32.92 per ton gold and silver. The average sludge assay for the same section is 4.81 per cent copper, and $\$ 1.40$ per ton gold and silver. Combining the core and sludge gives an average assay. for the hole of 4.62 per cent copper and 1.59 per ton gold and silver. 
The ccipletion of bianond Drill kole lo. 17 now rakes possible the prorile of the vein shorin on rny diagrarn of ore body. The indicated ore bocy averages 10.3 feet wicle, and contains approximately 27 , 000 tors of ore, assaying 4.5 per cent copper and 4.97 per ton gold and silver. istingted costs show that it should be possible, using a 60-ton per day mill, to mine this 27,000 tons of ore and reaiize a profit. The 27,000 tons of cre represent ore reserves for only 18 months operation of the mill, but during that time exploration should outine more ore reserves. The rill, once installed on the property, should be aole to operate for many years or until exploration justifies a larger mill.

Sampling and assaying shows the copper minerals, gold and silver, to be consistently concentrated in the west portion of the vein. The west 5 feet of vein averages 3.72 per cent copper, and 3.93 pey ton gold and silver, whereas the east 5 feet of vein averages 2.03 per cent copper, and 31.75 per ton gold and silver. Should mining costs be higher than presently estimated, the west five feet of vein could be mined, leaving the east 5 reet, and the mill still be operated at a profit. The ore reserves would then be approximately 15,000 tons, rather than the above stated 27,000 tons. This 15,000 tons would supply the mill for nine months. Again, exploration during the nine months of ralil operation should outline ore to keep the mill operating for many years, or until ore reserves justify a larger mill.

I am continuj.ng the diamond arill program and to date Diamond Drill Hole ko. 18 has reachad 100 feet.

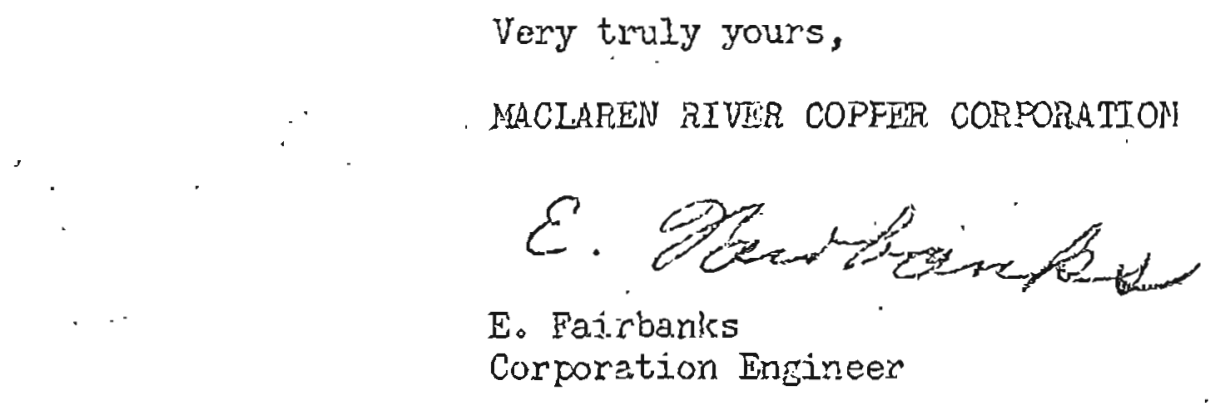

Date: February 14, 1958 


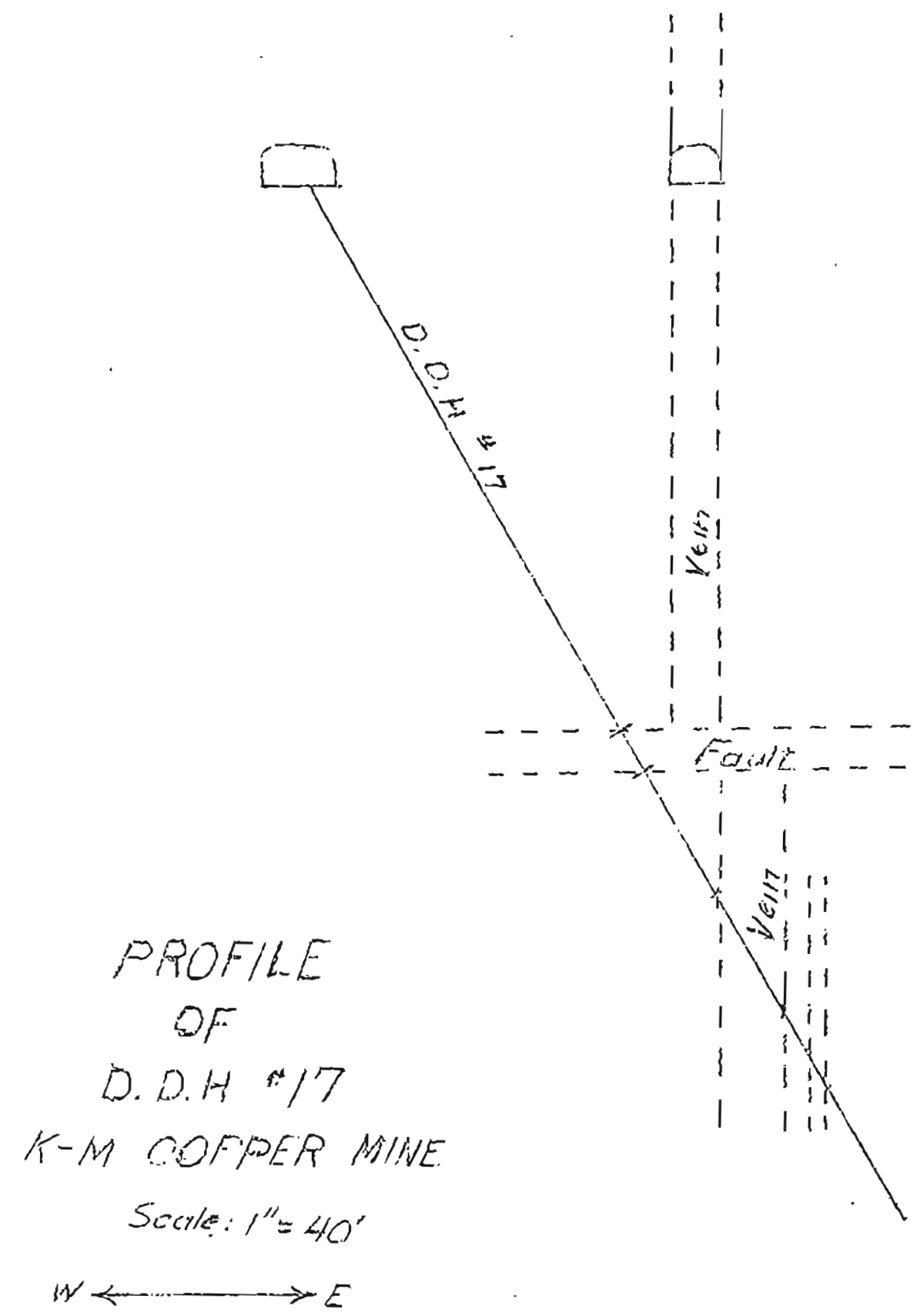




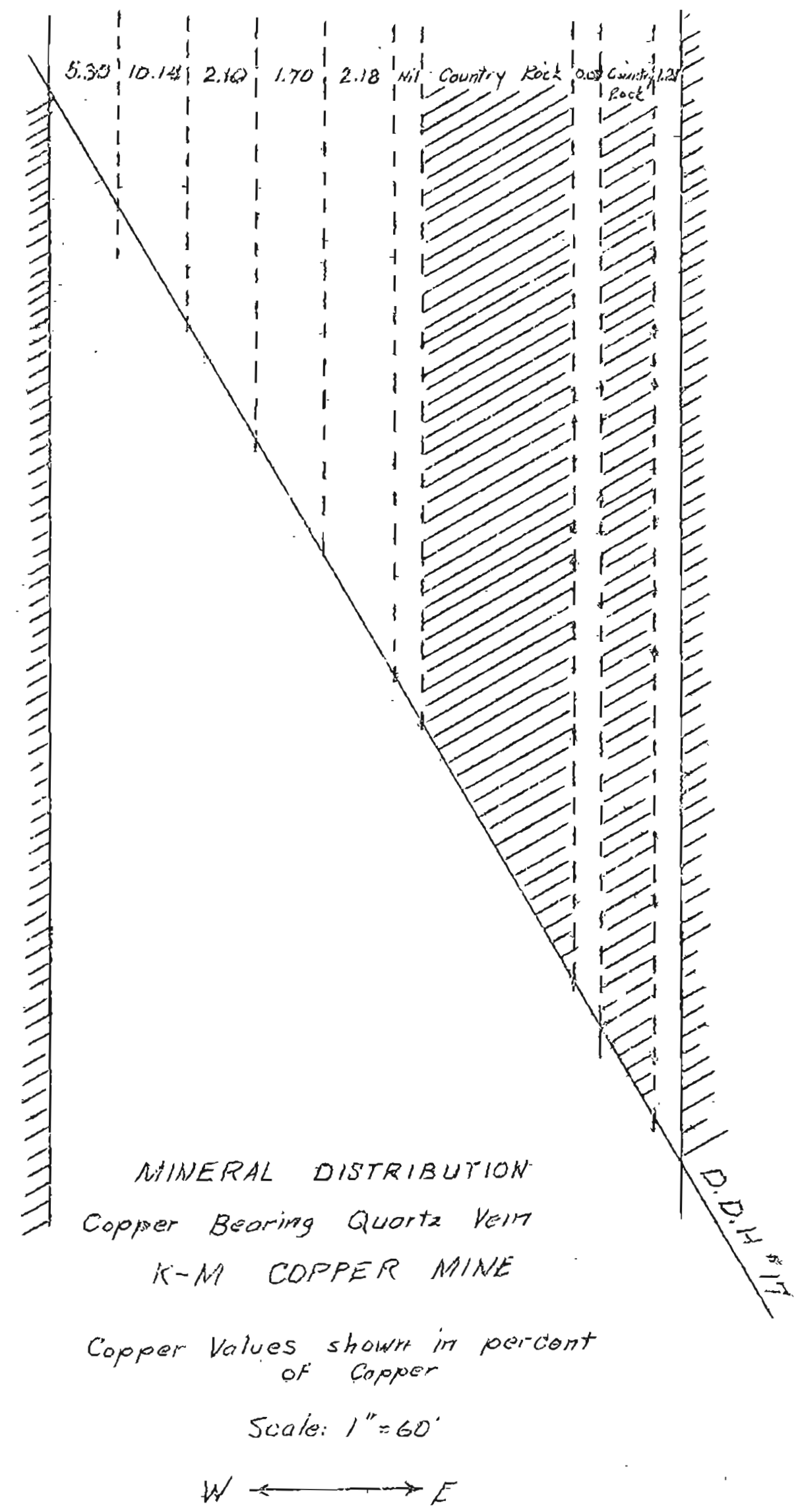




\section{WACIAAREN RIVER COPPER CORFORATION Box 1282 \\ Fairbanks, Alaska}

Decernber 12, 1957

To the Stockholder:

Attached is a recort by lir. E. Fairbanks, our ilining Engineer, pertaining to a recovery meshod commonly referred to as "scalping". It is a very simple mechod of recovering a hi-grade concentrate from mine-run ore, and is often uscd on small hi-grade deposits.

The mine-run ore, with no cinshing whatsoever, j.s screened to removo all oversize pieces, and is then run through a "Jig" which, through a water pulsating moyentent, sertles or concentrates the ore by gravity, in layers of different weights and draws off the heaviest layers (hi-grade) througin one or two openings, and the lighter materiais (low-grade) through another opening - thus separating the heavy mineral from the much lighter material. The attached report gives the detailed information and conclusions reached by Mr. Fairbanks.

Comencing with our second ycer of operations, we hope to keep all stockholders as fuliy inforned as possible of our work - not by a Quartexiy or Semi-ennual report, but as new develoments occur. This lettei and report are in line with this overall policy.

The minutes of the First finnual Stockholders meeting were wire recoried and ara now being transcribed. Copies will be forwarded to all stockholders in the very near future.

Mir. Adler Tatro has been einployed as Mine Manager of the K-K Copper Mine and is now in complete charge of the operations. Ris many years of experience fully qualify him for tris key position.

M. Frederick M. Wells, with e mining and business administration background, has been employed as Office Manager, and will also expedita ior the mine.

Our rijing Engineer, Mr. T. Fairbanks, is a graduate of our Alaska School of iitnes, with several seasons of field experience with Coodnews Bay Mining Company, and has a very solid mining background.

Our program of drifting and stockpiling of ore was completed in the middle of November, and we are now diamord drilling both shifts, as we must complete our drilling program before commencing our new adit, which will put us into our first production phase.

The ore shoot on which we were drifting is better than was anticipated, and $j_{1}$. Fairbanks is now on the K-Ki property making a complete new report with a new sempling and assaying program. 
As we go into our second year, our program has already doublerl; our crew has greatly increased; an office is boing set up; and we vill be in produc tion by Spring, as scheduled. Our estimate of returns will be based on Mr. Fairbanks sampling, assaying, and laboratory work, whereas previous ${ }^{p} y$ all estimates were based on four separate reports.

An estimate from our ow samples indicates that the original figure of a 6 per cent copper ore was very conservative, as sections of the exposed oie shoot run as high as 10 per cent.

The good news which we have all been snticipating will take some time to be confirmed, but a cquick look shows that the first diamond orill hole rached copper mineral at 115 feet of drilling.

At 130 feat of drilling, the vein was contacted at a point 150 f'eet directly under the drift iron which we stockpiled. As our vein is vertical, we drilled from a point 50 feet of to one side and at a downwam angle so we would recover a core of oie acruss the vein. As stated, the vein was contacted after drilling 130 seet. We have drilled, as of this dato, to 220 feet, and are still not only in ore, but in hi-grade ore, and are still in the vein.

This 90 feet of drilling has been in one continuous ore body, and even with the downward angle shows that the vein is at least 30 feet wide already.

Sirce cores are very difficult to recover, any true sample is rot possible, but from the sludges (ors ground up by the drill and washed up out of the hole by water pressure) and from the cores which have been recovered, indications are that another increase in copper at that depth is possibly as high a.s 8 per cent.

If the balance of the diamond drilling continues to be as difficult 25 this, no areinge parcentage of copper can be datemined, but this pirst hoie alone shows that the vein not only is richer at depth, but is also a great deal larger than we had evan hoped for. It may be much too soon to ever speculate on, as this is one hole which coula merely have intersected a large spot; or as is possible but hardly probable, the vein could have dipped (tumed), and we might be drilling parallel in the vein.

Jachinery, oil storage tanks, building meterials for the mill, mining supplies, additional equipment, fvel, eto. amounting to 8 semi-truck loads, are under way today into the rnire, and the new adit site, new mill building, and new tipple house are all of the drawing board and now under way. 
The now Board of Directors, as voted by the stockholders at the First Amual. Meeting, consists of the following:

$$
\begin{aligned}
& \text { F. S. Pettyjohn, Jr. - President and Chairman } \\
& \text { of the Boara } \\
& \text { E. O. Albertson - Vice Fresifient } \\
& \text { Thomas ki. Hyike - Vice President }
\end{aligned}
$$

In surmary, the outlook is brighier than ever; the ore on which we cormexly based ols estimates j.s hetter than was anticipated, and a fulj.ecale sampling prograto w1i bo carried out next summer on an additional showing of copper which has been traced for $3 \%, 000$ feet.

Pioduction should sommence thie Scrine, as planred.

$$
\text { Very truly jours, }
$$

AUCILAREN RJVER COPPER CORPORATION

$$
\text { F. S. Pettyjolin, jro }
$$

Presidont and Chajrmen of the Board

Encl. 
College, Alaska

Decenber 9, 1957

Wr. F. S. Pettyjohn, Jr.

MacLaren River Copper Corporation

Eox 1292

Fairbanks, Alaska

Dear lir. Pettyjohn:

Pursuant to your request, I have conducted Jig tests on eight samples received from you, and submit herewith the following report of the results of those tests.

Respectfully,

Ervon E。 Fairbanks

Milning Engineer

Enclosure 


\section{Sample Identification and Description}

Tests were conducted on each of eight samples. Two of the samples were received with no identifying narkings. For test purposes, the numbers $X-1$ ard $X-2$ respectively ware assigned to these two samples. The other siz samples were marked as follows:

Sample No. 1 - November 9 $38^{17}$ 연 $45^{\circ}$

Semple No. 2 - November 9 $31 "$ " $45^{\circ}$

Semple No. 3 - November 9 $36^{\prime \prime}$ (3) $45^{\circ}$

Sample No. 1 - November 17 Fault $38^{\prime \prime 1}$ @ $45^{\circ}$

Sample No. 2 - November 17 Fault $72^{11} @ 52^{p}$

Sample No. 3 - November 17 Fault $61^{1:}$

The head ore assay of the above jaentified samples is as follows:

Sarmple $\mathrm{X}-1$

Sample $\mathrm{X}-2$
Sámple No. 1 Nov. 9

Sample No. 2 Nov. 9

Sample No. 3 Nov. 9
12.95 per cent coppor 0.18 ozs. per ton gold I.44 ozs. por ton silver

6.98 per cent copper 0.02 ozs. per ton gold 0.48 ozs. per ton silver

7.63 per cent copper 0.06 ozs. per ton gold 0.96 ozs. per ton silver 2.67 per cent copper 0.06 02s. per ton gold 0.64 ozs. per ton silver 5.46 per cent copper 0.06 ozs. per ton gold 1.18 ozs. per ton sliver 


\author{
Sample No. 1 \\ Nov. I'? \\ Saraple No. 2 \\ inov. 27 \\ (See Sample No. 3 below)
}

1.52 per cent copper

0.02 ozs. per ton gold

0.18 ozs. per ton silver

2.16 psr cerst copper

0.18 ozs. pel" ton gole

0.48 oze. per ton silyer

\section{Object of Tests}

The object of the tests was to investigate jig treatment of the samples, without crushing, grinding, or chemicai treatment of the ore, to produce a copper-gold concentrate and the percentage of total coppor recovered in that concentrate.

\section{Treatrient of Samples}

Samples $X-1$ ard $X-2$ were dried, coned, and quartered. One quarter of each sample was screened, using $1 / 4$ inch screen. One quarter was screened, using $1 / 2$ inch screen. The remaining six samples were dried, coned, and halved. Half of each of these six sarnjes was screened, using $1 / 4$ inch screen. A portion of each of the eight samples was taken for head ore assay. The unused half of each of the eight samples was storeci. for fucure tests.

The oversize material which passed over the screen was discarded. The undersize material which passed through the screen was treated,

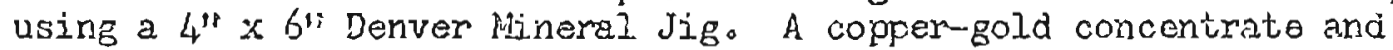
a tailing for each sainple ard each concentrate and tailing product was assayed.

\section{Results of rests}

Fortions of samples $\mathrm{X}-1$ and $\mathrm{X}-2$ were screened to $1 / 4$ inci and $1 / 2$ inch to determine tine effect of size of jig feed on recovery. "The results of the tescs on these two samples as shown on the following data sheets indicates that higher recoveries were effected as a result of the screening to $1 / 4$ inch. For this reason, the remaining six sampies were screened to $1 / 4$ inch only.

The results of each jndividual test vill not be discussed, as those results are shom on the data sheets. It will only be said that combining the results of the tests that the concentrate which represented $5.26 \%$ of the original weight contained $30.53 \%$ of the copper, $6.96 \%$ of the gold, and 29.43\% of the silver from the original samples and had an average assay of $4.6 .17 \%$ copper, 0.19 ounces per ton gold, and 5.31.\% ounces per ton silver.

$$
\text { Sample No. } 3
$$
Nov. 17

\author{
6.23 per cent copper \\ 0.34 ozs. per ton gold \\ 1.08 0zs. per ton silver
}




\section{Conclusion}

The regults of tine tests show that a jig alone couid produce a high grads coppar-gold concentrate from the virnples subritted and at the same time effect good recorery. It is the suthors understanding that the tegted semples were not mine run ore but chanilel samples. The results of the tosts would noi apping for mins run ore unless the mineral were fireed to the sane exterit as the mineral in the samples tested. Since good rosults rere obtained in these tests, similar tests should be made hisirg mine run ore. 
WACEAREN RIVER COPPTR CORPORATION

\author{
1016 polaris \\ Fairbanks, Alaska
}

October 15,1957

Inclosed you will find a Brochure which we are mailing to each of our stockholders in Alaska. We hope you will study this literaikse thoroughly and join our corporation through a purchase of stock; then pass this inf"ornation on to your friends.

If you purchase stock, immediately upon receipt of your check either through the mail or by one of the corporatjon repiesentatives, you wj.l receive $a$ duplicate of this Brochure, plus a receipt and letter of acknowled-jucht. Your sotck certificates will follow at the exinlest possible dat, s.

Pirst in tiris Brochure is a copy of a letter to one of our present stockholders, followed by a Prospectus containing a brief hiscory of our corporation and its objectives.

Folliwing the Prospectus js a leiter to the stochiholders which we inc?ude to shor you the aimis and anbitions of our group. If you snouid decide to ioin our company, we hope you will give the Articles of Incorporation and the 5y-laws a very close study, so that when you attend the fjirst Lximus? Etrokholders" moting on Decenber lst, you will be abie to assist jn the passing of additional By-Laws which vill gorem the corporation.

A glance at the Ljst or Stockholders wizl show you that no one person, or group of persons, controls this corporation, and it is our intention thet this situation will remain as it is.

This corporetion was Pormed without the eid of a promoter and no atock has been isised for promotion purposes, good will, on bolow the per value figure of $l_{\circ} 00$, We conform sticicty to all Security Rychange Comission rulings, and if at some time in the future it should become necessary to sel!. ackitional shares, they can be piaced on the macket outside.

Yo:d will note that we do have a limited number of outside stockholdeis. but this present offering of 100,000 shares (at the far value of lil $_{0} 00$ ) is being made only to persons residirg in Alaska.

An jnventory of equipment, owned by the corporetion (落]6, 600 is due the Alaska Freight Lines as the final payment on this equipment) is imeluded, and we wish to enplosize that the corporation owns all of the ground ointright with no ljens or encumorances. We also own the $5,1,00$ foot cormercial airfont, the camp site, the mill sita, and have absolute contro? of ail water in the creek winich will supply our hrdomelectric rower for our lerge raili.

Jise are now Diamond Core Drilling and Drifing on an ore shoot to finish checking out (a method of exploration to detemine tonnage and minara? rarccontage) on an ore body of sufficient tonnage to operate a 50-ton mill, 24 hours a day, for tivo gears. 
The United States Govermment shares the cost of this exploration work by \& Defense Exploration Contract under the U.S. Department of the Interior, Defense Minerals Exploration Administration, Washington 25, D.C.

The cost of the program is estimated by stages; the first stage corsisting of Diamond Drilling, the second stage of Drifting, and the third stage of raise and levels, and is shared equally by the Government and the operator. In our case, of course, the Operator is also the owner.

Our contract calis for a fifty-fifty share of the overall cost, but instead of each paying 50 per cent of the monthly bills, we estimated all labor, equipment, fuel, powder, groceries, freighting, etc. by the footage of work performed, i.e. Diamond Drilling @ 12.00 per foot, Drifting on one level @ 48.00 per foot, Drifting on the No. 5 level @ \$38.00 per foot, etc. This the Government at the end of each calendar month sends a representative to the property to measure the footage accomplished and to see that the work is according to specifications. As soon as his report is filed, we are reirabursed for the Government's share of the work performed during that month. For example, in Diamond drilling, with 600 feet completed 12.00 per foot, the covernment"s share @ $\$ .00$ per foot amounts to $\$ 3,600.00$.

The money is loaned against production of the mine, carries no interest, is repaid by a percentage of the smelter returns not to exceed $5 \%$, and is cancelled at the end of 10 years if not repaid.

This particular type of loan can and often does continue for years, even after production has commenced, since in some cases the small mill is used to gay the companyis share of a very large program to develop tonnage for a mill from 500 tons and up.

Estimated returns, cost estimates, and all related information are contained in the pages following.

Questions have risen in the past regarding the size of our corporation $(1,000,000$ shares) in relation to our estimated total issue of only 300,000 shares. These 300,000 were voted toward the purchase of the K-M Copper Mine (I7 lode mining claims), purchase of all mining machinery and buildings on the property belonging to the Alaska Freight lines; financing of an exploration program; a mill and the installation thereof; and working capital sufficient for operation until smelter returms are banked. If the funds received from the sale of the 100,000 shares now being offered are not sufficient to complete this operation, then more shares must be voted to be sold, but will undoubtedly be at an above par value figure (\$2.00 or more per share).

As you will note when going over these papers, the K-M Copper Mine is not all we are relying on. Should there be a market slump, or should ore reserves become depleted, or some contingency occur not allowed for in our estimates, our plans include having other properties onto which we could move.

It was our intention to carry on an extensive prospecting program for both minerals, and oil and gas during this fast season, but because of limited financing the program was limited to three men in the field for only 30 days. Fortunately, several nice showings were made, one in placer, and one 12,000 foot showing of copper indications adjoining our property. The latter is being staked, and will belong to the corporation when recorded. 
We plan to continue work on the copper mine throughout the winter, and if possible will install our mill. We are at the present time working a D 8 Dozer on the mill site, and hope to have the mill installed before the heavy snows prohjbit outdoor work.

The accompanying photographs show you something of what we have. These were taken this summer (1957) after a temporary shut-down of the mine prior to commencement of work under the D.M.E.A. contract which became effective September 10th. On this date, we re-hired a crew (including the cook) on a sub-contract basis, at a spocified doliar amount per foot of work accomplished. This has reduced the cost of labor by better than 30\%, increased production, and made for better overall efficiency, while at the same time increasing the employees take-home pay very substantially.

The last page of the enclosures is a form letter aderessed to the Geological Survey requesting a circular on the K-M Ccpper Mine. This bulletin, together with the other enclosures in this Brochure, gives each stockholder a start on a complete written record of his corporation, to which he vill add from time to time as explained in the letter to the stockholders.

Briefly, this Alaska Corporation actually began on June 19, 1953, when a team of prospectors (E. O. Albertson and F. S. Pettyjohn) made the original discovery on this property. (See U.S. Geological Circular 332). It Erew to the Partnership of Albertson-Pettyjohn, then to the KathleenMargaret Mining Company (under which the first D.M.E.A. money was obtained), was sold to the Alaska Copper Mines, Inc. for $\$ 1,000,000.00$ in 1954, was returned to the Kathleen-Margaret Mining Conpany for nonpayment in 1956, and was then purchased by the MacLaren River Copper Corporation immediately following its incorporation in Noverber of 1950.

After a close study of the enclosed information, if you should decide to join us in this corporation, receipt of your check makes you an authorized stockholder, owning the same number of shares as your check is made out for dollars, Again we ask that you pass this along, as you receive your own identical copy upon receipt of your purchase.

Very truly yours,

MACLAREN RIVER COPPER CORFORATION

F. S. Pettyjohn, Jr. President

E. O. Albertson

Tin.าละ

Secretary 
HALARIN RIVER COPPER CORFORATION

I015 PoIaris

Foirbanks, Alaska

October Iibs 1957

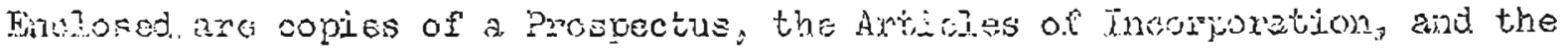
By- Inve of ycum corporation. together with other pertingrit materian.

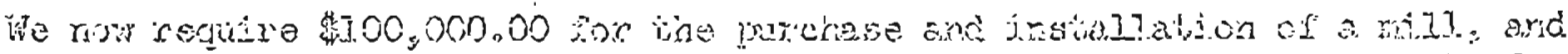

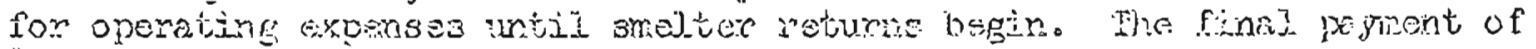

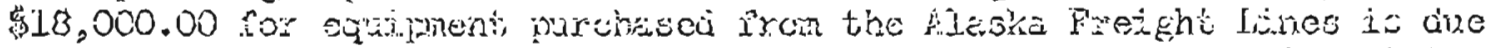

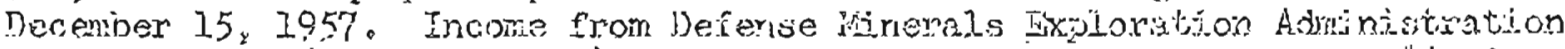

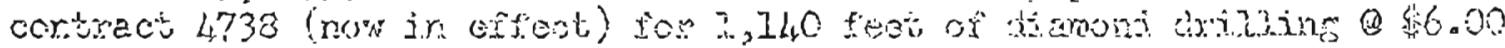

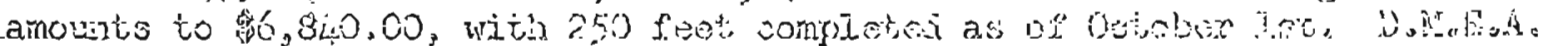

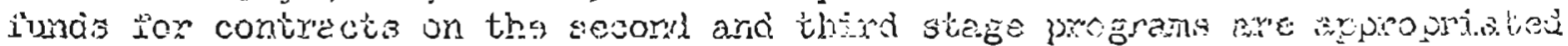

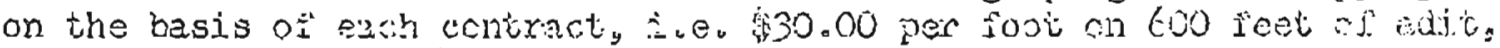
etco

As we wish this to reingin a closed corpration, and do not wint to soerd tire and money ir meiring a nulic suse, we are sending this infornation tr. ail of our present stockioldexs tho resile in Alaske Sinvo it is to the

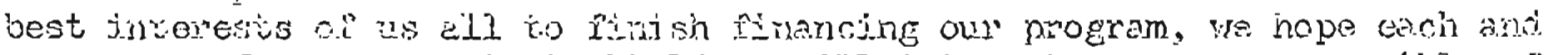
every ono of on phesent siockholiexs will intesest as many as possible of

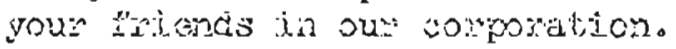

We are now orfering 100,000 shures sow sale ait,

$$
\begin{aligned}
& \text { Shares cold is date } \quad 275,123 \\
& \text { Shares subscribed to } 2 j_{10} 000 \\
& \text { Chares available } \quad 098 \mathrm{dri} \\
& \text { itivyber of total shares catschndirg } \\
& \text { a) complesior of present issue } 300,000
\end{aligned}
$$

The romaining 700,000 shares may be sold at a lates date, for future financing on this mine or for other investnents, at an above par value figure, or may bo held by the corposation as noin-paying stopk. only the shenes issued to stockholders will por djvidends.

Sales from pio.00 (for 10 shares) and up rill bo accepted is we will need some political help in getting ous $x=3$ s pogram through, the more smal.l 3tockholders we have, the more pojicical jiofluence we will have. 
We are entitled to sell stock through the mil, so that checis can ba sent, to either of the following addresses:

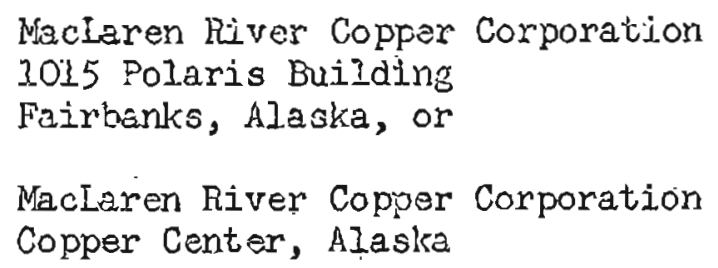

Checks will be acknowledged with a corporation receipt by return mail, and literature identical to that received by you will be forwarded. The receipt for the check will make an authorized stockholdar of the purchaser, and stuck certificates will be issued at the earliest, possible date.

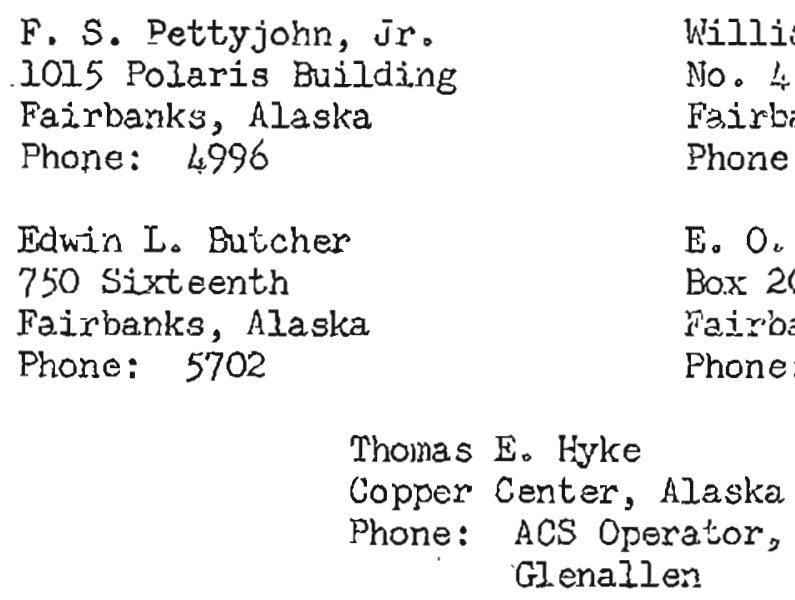

A samole check is enclused illustrating the manner in which checks shouid be made out for the purchase of stock.

Wr. Albertson has been elected as Secretary, and Mir. Major as Treasures, to cerve as such untjl the Arnual Stockholders meeting on Decernber Ist.

Very truly yours,

IFACLAREN RIVER COPPER CORPORATION

F. S. Pettyjuhn, Jr.

President and Chairman of the Board of Lirectors

N. O. A].bertson

Secretary

Fincls. 


\section{MACLAREN RIVTR COPPER CORPCRATION}

\section{PROSPECIYS}

\section{YTS SORY}

Articles of Incorporation for the Wediaran River Coppe: Oorcowatus

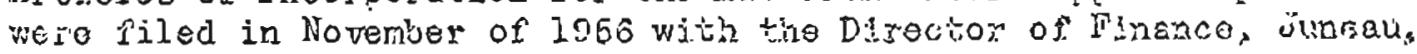
Aiska. Fersons signing the Articlos of Ircosporation papers, and nembers of the Board of Directers sol the first yoars are:

$$
\begin{aligned}
& \text { F. S. Fottyjohn, Jin - Tresident } \\
& \text { Joh Koward Bayleso wise Presidert } \\
& \text { Barl. B. Beistline - Sovretaly-l'seasurer }
\end{aligned}
$$

This company is capitalized at $1,000,000$ sheres of stuok with pax value being 1,00 por shara,

TI. OBJECTIVTS

A.r. Gene:

The overall oujective of the Corporation is to enfege in praspect, ing, expioratlon, end mining of mineraj daposito in tiaska.

B. Speotific

The indtigl etfoits of the Corporation aro being directed toward erploration work on the Kathloev-Mastuaret (Km) Copper Prospect. ycw owned by the Macuaren River Copper Corporation. It is localos on the Uppor Macharen Rivor, Third Judicial Digtuict, Tajleeciso Racording Procinct, Alaska.

The onpper prospect lay 12.5 miles zorth of tho Mactaren inver hrtdge on the Denall Highway (hiilo 42 ), and consists of sixteen lode mining claims recorded at Wasilla, Alaska.

Trehching at 100-foot intervels with a D-8 Caterpillar has exposed 1,700 feet of vein. An additional 3,600 feet has been indicated by hand trenchitug and ouccrops. A separate ore bodiy has been indicated by cosper showings along 12,000 feet of mountain-top.

III. PLAN OF MORK

me Kaj Prospect was located in 1953, add was leased by the Alaska Conpor Hines, Inc. (Box 3365, Seattle, Wachington) who began an exploration program. $I_{2} 1356$ the ground was purchesed by the Wactaren $\hat{R}$ i ter Copper Corporation. 
A representative of the Corporation visited the Denver Equipment Company of Denver, Colorado immediately following this purchase, and sattsfactory arrangements were made for the purchase of a 100-ton mill, at the time it ehould becore warranted. The Tacome Smelter, at Tacoma, Washington, was personally contactod and a tentative agreement reaohed for the acceptance of all ore shipments.

A. Work above Ground

Work accomplished above ground includes the following: construction of a 5,400 foot commeroial elrport under a 20 -year lease from the Bureau of Land Management; construction of mine roads; constructicn of a oompletely equipped 14-man camp, fully modern, gravity flow water, eleotricity, eto., cousisting of the following rajor units - two 7-man tunkhouses, one messhall complete, with kitchen, cooks quarters, storage room, and wesh house; a separate office buildings: a $30^{\prime} \times 6 Q^{\prime}$ Butler steal shop and garage; and inoidental out-buildings.

A mine tipple weis constructed, and consists of a compressor house, machine shop, warm-up and Iunch house, and an underground Iight plant station.

B. Work Underground

Underground work has been acoomplished as rollows:

$550.2 \mathrm{rt}$. of drift paraliel to the mineralized Zono

$95.0 \mathrm{rt}$. of orosscuts at two locations and which intersect mineralized zones

$110.0 \mathrm{ft}$. of raise

$73 i .0$ ft of peroussion drill prospecting

$676.0 \mathrm{ft}$. of diamond drill prospecting

$70.0 \mathrm{ft}$. of drift on an ore body

Work accomplished by the Alaska Copper Mines during 1954 and 1955 indicates, by diamond core drilling, that several minable ore bodies exist. One ore body, conslsting of approximately 25,000 tons of minable ore, was blocked out by diemond core drilling.

(Authority: "Work Progress - Aleske Copper Mines").

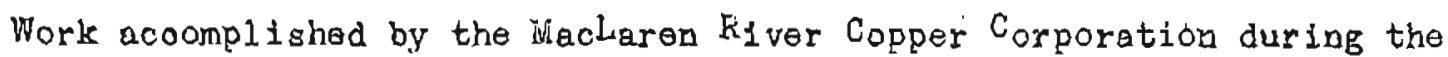
sumer of 1957 proved the existence of this ore body. hork consisted of driving on the ore body, stockplling ore, and sampling and assaying at given intervals. A Defense Winerals Exploration Adninistration contract for additional diamond drilling, which will prove this ore body to a depth of 400 feet (approximately 40,000 tons) is now in effect, of which the D.McE.A. is partioipating in the amount of $\$ 6,00$ per foot for this par-ticular program, which calls for 1,140 feot of diamond drilling. Stookpiling of this ore continues. One diamond drili core has been recovered at the 360 foot level on this ore body by the Nacharen River 
Copper Corporetion, and shows nessive Bornite, There is an addi-

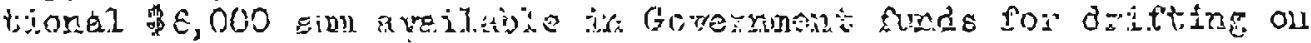
this body, irevaraticne liato been made to contialie operationa throughong tia wintor.

Tron the completson on "so feet of driljing on the main ore body, tlog D.M.E.A. has indicated willingnese to parti.clpate on $\theta$. new tinple site, which will move the portal for our uncerground workirigs down the nountats to a more convenient locetion. From this n.sw tipele site, the int3rsection of the first ore body will bo mede eti a depth of epproximetoly 5no feet; effording th: ye years



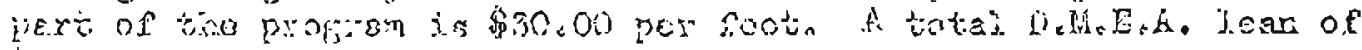

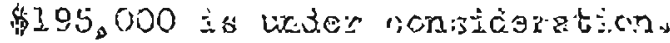

Cocstdereble prosponting was csured on thas summer and as a result,

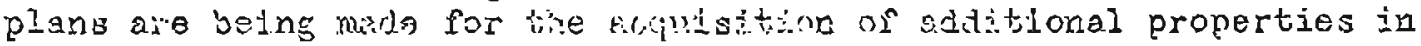
the near future. Flacer ground has been mado avaijable to the company, and consideration is being given to the devsiopreat of a large coai r̂jeì.

Work done to date, together with some additionel diamond drilling yeit to bo oompleted, proves that the installation of a 50 -tan mill is fully warrsoted, and we are at presont negotiating the purchase of a -nil. locailyn Wiager, as euch, have been discontinued, stnce all iabor tit the mine is being porformed on sub-contract, based on the fontage driven, ft precent there is a boman crew working on the propertiy.

\section{FINANCING}

Apro:07inately $\$ 50,000$ has beea raised to date. Of this sum, approxiincisiy $\$ 9,000$ has boen erpended on groceries and suppijes; $\$ 9,000$ has been invertis in additional equipmen'; 12,000 has been paid teward the 30,000 Furchase price for all the mining equipmert and bulldings on the rro-

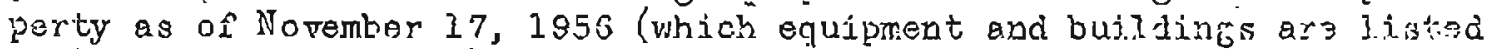
at $\$ 30.000$, installed)

1he remainder hes covered the costs of clearing of access roads; truck" ing of supplies, construction of new bulldings, maintenance, salaries, taxes, etc., with a very minor amount having been spont in organizing tho Corporation.

It is now proposed to offer stock at $\$ 1.00$ per share in the emount of an Rdditional 125,000 sheres, which will bring the number of tote? sihares oxtsiendiry to 300,000 . This figure includes, also, the shares paid for the K L Copper Prospect.

This stm is required to maet current expenses, to pay the $\$ 18,0,00$ bajence on ecuirment and buildings, to install a mill, and for uss as operatiye capital ponding recespt of smelter retums. (it is conserratimaty estimated that the returns on the 50-ton mill will approximate $\$ 1,500$ per day). 
Shsires in the corporation, before thy are re-solu. aither in frivato or on the nariketi, must be cffered to the conpoziticn ot theis thon. current oalue,

Shares may be puzohased througit the followirg authorized representatiresa

1

F. S. Peisjolin, Is:

Pons: 1996



Intrbanki, fil Rsica

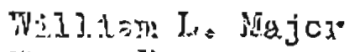

Xoo \& wa

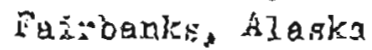

Yidwin L. Butclior.

TSO Stzhearth

F'alroorkg, Alasta.

E. O. Albertion

BOx 2058

Tai-bonks, A?aska

Thomas E. Izyza

Copper Dodyei; Aloska :hons: 3058

Phono 570?

Phone: 2.SOS

Tnono: ACS Cparatos. Glaacllen

Date: Jotriber 10, 1.55? 


\section{SUPPTEMENT TO FROSPECTUS}

The Defonse Minerals Exploration Administration is participating in the exploration program by reimbursing the corporation in dollars per foot.

Finst Stage

The first stage consists of diamond core drilling to a depth of 410 feet below the surface outcrop to block out an additionsl 15,000 tons of ore. Diamond drilling now being done is estimated at $\$ 12.00$ per foot, of whioh the Covarnment is paying us at $\$ 6.00$ per foot.

\section{Second Stage}

The new adit will consist o.t an estimated 600 feet of drift to intersect the ore body at a depth of 500 feet below the surface of the outcrop. The cost of this drift is estimated at $\$ 60.00$ per foot, of which the D.M.E.A. has indicated their wllingness to participate in the amount of $\$ 30.00$ per foot.

\section{Thira Stage}

A raise, with levels off the raise at 50 foot levels, on the ore body, is the third stage, and the D.M.E.A. has indicated their willingness to participate in this program also. The cost of this raise and different levels is estinated at from $\$ 75.00$ per inot for the raise, to $\$ 150.00$ per foot for a winke, depending upon the difference in elevation from the haviage drift.

A rough figure on footage-tonnage is 5 tons per foot.

On this third stege, raise and levels, the DoM.E.A. porticipation is estimated st 5.00 per ton, as all of the third stage work wilj. be performed on the orebody.

At least one years $\mathrm{mill}$ feed will be mined under the D.M.E.A. participation contract: thus reducing our cost of mining to an estimated 83.00 por ton, or reimbursement of $\$ 250.00$ per day. After the ralse and levels are criven, the cost of mining is then reduced to approximately $\$ 3,00$ a ton by stoping.

The actual cost of $\$ 8.58$ per ton of ore is still estirated, as we consider this 50-ton mill to be a pi.tot mill and to pay for exploration costs to develop an ore body large enough to install a will with a capacity of 500 tons or more, as we can then mine as low as $2 \%$ ore, depending upon the market.

A hydro-ejectric site sufficient to develop power for a 500-ton mill is owned by the company, and is covared by KrM Clains No 5.7 ; 11 , and 12.

Even a rough estirate on a 500-ton mill is impossible at this stage, as we cannot be certain yet that the ore is of sufficient grade or continues to a depth necessary to warrant another mill. 
Supplement - Page 2

The D.M.E.A, participation costs have been figured in footage, as approximately 50 per cent of the costs of the program are in the equipment, buildIngs, supplies, and minoroads already paid for by the corporation.

\section{Shipping}

Shipping will be on an open contract submitted to various trassportation companies. Concentrates will be shipped vie truck, barge, or ship, directly from the mine to the smelter.

Concentrate containers will be canvass bags, paper bags, heavy cardboard boxes, or 55-gallon drums. Negotiations are being carried on with various bag and box manufacturers regarding a container which can be durped full of concentrates into the furnace, whych will result in a saving in smelter charger.

Expexinents are al so being made in selation to a binder in the wet concentivate, which concentrate could then bo molded into blocks and shipged witiout containers.

\section{Nining}

The ooct of mining and milling per ton of ore wes arrived at during the sumier season of 1957, as the DoMa.A. controct did not becoma effocitivo latij. Sev. tember 10, 1857. Intensive expertnents vere conducted in mining and wiling: costs. Certain portions of the work accomplished was in relation to the sorting of ore. For examplo, by mining more than 50 tons per dey for the rill (say 60 tons) and ruoning this 60 tons of $6 \%$ ore ovej a sorting belts 1 it is possitle that the percentage of 50 tons of mill fead could be increasod to $7 \%$ by sorting ont 10 tons of barren quarte, losing 200 lbs. of coppel in the prosess. Sorting tests are still being run, and it is speculated that the cost of the sorting would be about 42.00 per ton. This $\$ 2.00$ cost would 1nerease the value of the ore by $\$ 6.00$ per ton.

The gold and silver oontent has not been figured in the estinated returnis, but ohould run froro 1.50 to $\$ 4.00$ per ton. This was not jucluded in the estinete because tests are still being rum by the Denver Equipment Company,

Verisication was made this sumirer of an ore body 10 feet wide, 100 reet; lon: and 250 feet in depth whioh contains 24,000 tons of $6 \%$ copper.

Eccal purohase of a 50-ton milling unit is under consideration, and vill be decioga upora bofore Decointer lot. Through local purchase, it is possiblo to isstali and put into oporation a 50rton mil: for approximately $200,000,00$, 


\section{MACLAREN RIVER COPPER CORPORATION \\ Box $\triangle 001$ \\ College, Alsska}

October 11, 1857

To the Stockholder:

The first Annual Siockholders' Meeting of your oorporation will be hsld at 1:00 pam. on Sumday, December 1, 1957 at the Eagles Fall, 547 Fifth A venue, in Fairbaniss, Alaska.

Election of officers for the forthcoming year will be made (the method. of roting to bo explained prior to the meeting); nembers of the Board of Directors w11l be voted upon; a comprehensive financial presentation will be made; this past year's performance and future plans of the corporation will be outlined, with certain aspects of the K-BS Copper Mine being decided upon by yote of the Stockholders prior to the electr.on of the new Board of Directors; and a general question and answer period will conolude the meoting.

Your presence at this first important meeting is highly desirable; how aver, in the event you cannot attend, we enclose your Proxy, which enables you to vote on the matters at issue. It is your privilege to name any Stockholder, whom you oonsider qualified, to use your votes at his discretion. Since this is your corporation, it is urgently requested that you exercise your right to vote. Your Proxy should be mailed so that it reaches its recipient at least ten days prior to the date of tho meeting.

Minutes of the meetings held during this past yeat by the Board of Directors will be read and plaoed in the Minutes of the Annual. Stockholders' beeting. A complete transcript of all business transacted at the Anual Meeting will be mailed to each Stockholder. This will give you a full record of all the activities of your company since its incorporation on November 17, 1956. Although this is not comon practice, and is not required by law, it in our wish that the mailing of the Minutes of every annual meetiag (into which will be read all business transacted during the preceding year, together with plans for the sucooeding year) will continue in effect.

Also enclosed is a copy of the Corporation's Articles of Incorporation, and a copy of the Byduaws. Additional By-Laws may be passed by the Board of Directors as the growth of the Corporation may make necessary, with regard to business and business methods, and the powers, dutios. 
responsibilities, and limitations of the Geaeral venager and the Board of Directors, The preliminary Bysaws, so important to the future of your Corporation, will be voied upon by the Stockholders (rather than by the Board, as is common oractica) at this First Annual lifeting; Thus your vote (or Prory) gives you a voice in the forming of the prin ciples of this organization.

During this oritical first yeax, your Corporation limited expenditures on office overhad to an absolute ninimum, in the conviotion that actuas. work and progrsss of the mine itself were of paramount inportance. Boosuse or this limited overhead budget, the plannod Interim Reports for thto year were not issued, a separate offico was not established, ana the greater percentage of the business was transactod from the $\mathrm{x} \rightarrow \mathrm{kl}$ Copner Mine:

In gddition to his regular duties, your. President (because of this strict limftation of funds) assumed the responsibjicty of ald finanoing: omplojnent on competarti persomel, with the attendent duties of payment

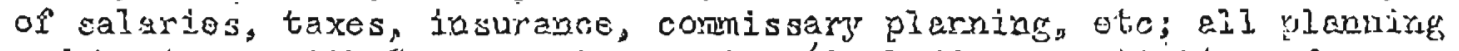
and business with Governont agencies (including negotioticn of costracts, road construotion, alid airport facilitiea; nisi full manaponeint $0 \hat{i}$ the mine (including onginooxing, and road ond lvilding equipment and supplies). As your Cosporation expands and ciroumbtances warrant, disiegavion of many of these duties will be made.

In the best interests of the Corporation, any change in your mailing. adóress ahould ba forwerded as goon as possible.

FOR THE BOARD OF DIPECTORS:

RRACLAREN FIVER COPPER CORPORATION

IF S. Pottyjohn, Js。

Chairman of the Poard 


\section{P.RQQ $\underline{Q} \underline{Y}$}

Knoin all mer by these presents, that $(I$, we) do hereby constitute and appoint (Stookholder) - e.tenraey and agent for (me, us) and in (my, our) mame, plaoe, and stead, to vote as (ryy, our) proxy at the First Annual Stookholders' Weeting of the Maolaren River Copper Corporation, eocording to the number of rotes (I, we) should bo entitled to rote, if then personally present, and authorize to act for (me, us) and in (my, our) name and stead at said meotIng as fully as (I, we) could act if gresent, giving to said

(Stockholder) - dgent and attorney, full power of substitution.

(Thls Proxy is to oontinue in force until unless sooner revoked).

IN WITNESS VBEREOF, (I, wB) have hereunto set (ny, our) hand and seal, this day of November, 1957. 
LIST OF STOCKHOLDERS

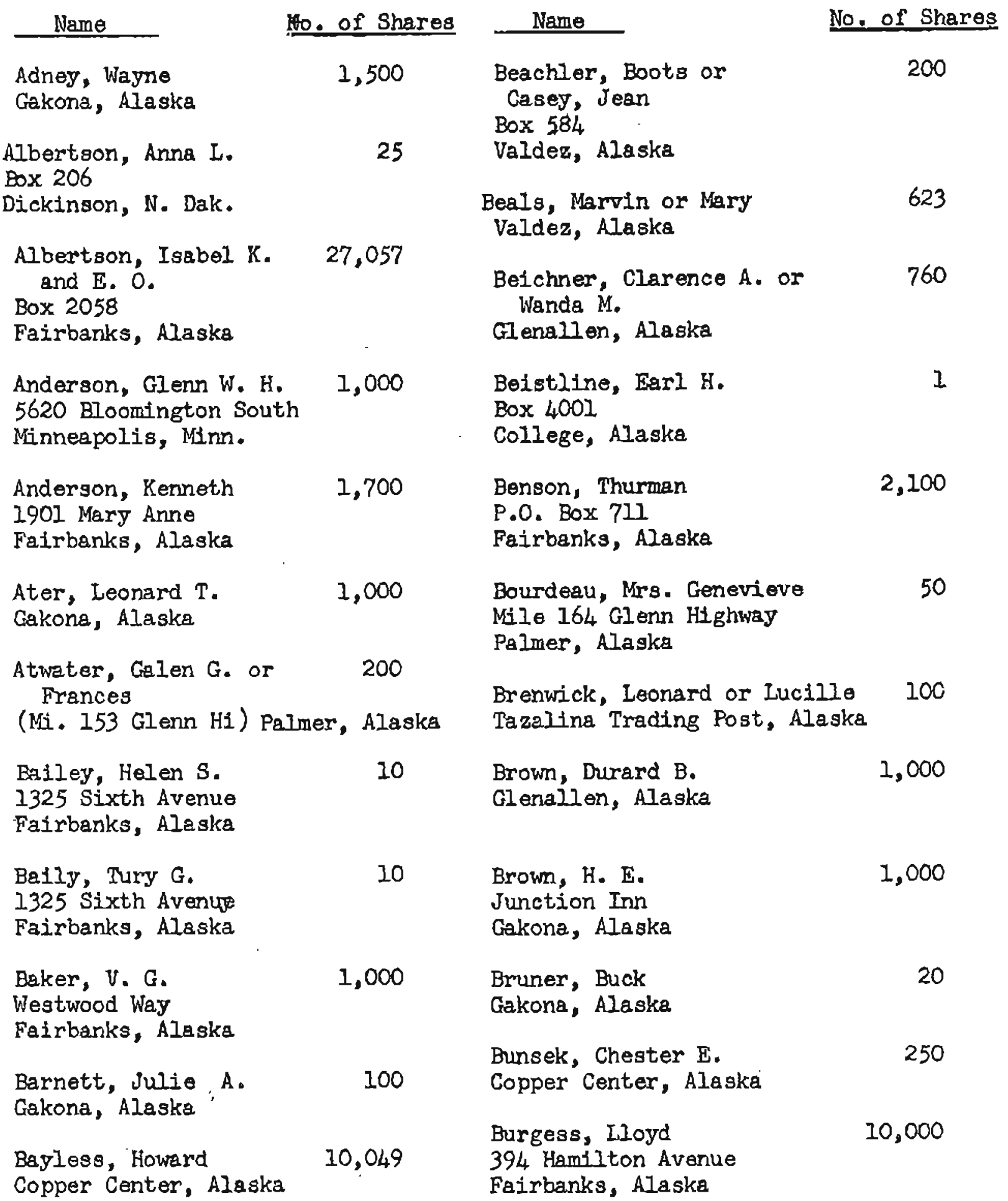


Name

Butcher, Edwin L or

Flossie

750 Sixteenth

Falrbanks, Alaska

Butcher, Gary I.

1533 Turner

Fairbanks, Alaska

Butcher, Mrs. Helen

Box 1206

Spenard, Alaske

Callahen, John $\mathrm{K}$. or Violet

CWM School

Ft. Groely, Alaska

Carper, Jamea R.

P.0. Box 7586

Portland 20, Oregon

Cease, Bernice Conion

637-1/2 Seventh Ave.

Anchorage, Alaska

Chamberlain, Glenn M. or 1,000 Mederese $M$.

529 A. Street

Anchorage, Alaska

Christopherson, Teresa

Gakona, Alaska

Cohoe, C. B.

$322 \mathrm{High}$ Street

Bellingham, Washington

Columbo, Louis $P$.

CWM School

Ft. Greely, Alaska

Cooper, George Proctor IV

9554 Sunset Ave.

LaMesa, California

Darks, Gilmer Owen

171 Chase Drive

Fairbanks, Alaska

Dempsey, Mr. or Mrs. Harry 500 Box 1981

Fairbanks, Alaska

100

50

200

150

50
No. of Shares Name

No. of Shares

Derrick, John H.

625

Box 14

Fairbanks, Alsska

Devault, Jack or Dorothy

967

(Devault Servico Center)

Valdez, Alaska

Dieringer, James $F$. oor $\quad 1,131$ Nore

Valdez, Alaska

Ditmen, Bob

1,000

Valdez, Alaska

500

Donald, Jack

Gakona, Alaska

Donald, Robert I.

250

Gakona, Alaske

Donnelly, Joseph T.

c/o Bureau of Publio Roads

Box 1600

Fairbanks, Alaska

Dunnagan, Earl

3,000

Valdez, Alaska

3,500

Eckhart, Charlos

c/o Boyd Hanson

428 E. Hennepin

Minneapolis, Minnesota

Fairbanks, Ervon E.

3,000

Boy 475

College, Alaska

Fairbanks Plumbing \& Heat- 1,000 Ing-Sampson Hardware

Pairbanks, Alaska

Falquist, Roy J.

200

Chitina, Alaska

Finnigan, James

c/o Wh. P. Cameron

1550 Gillam Way

Fa1rbanks, Alaska

Flowers, Arlington C.

Gakona, Alaska 


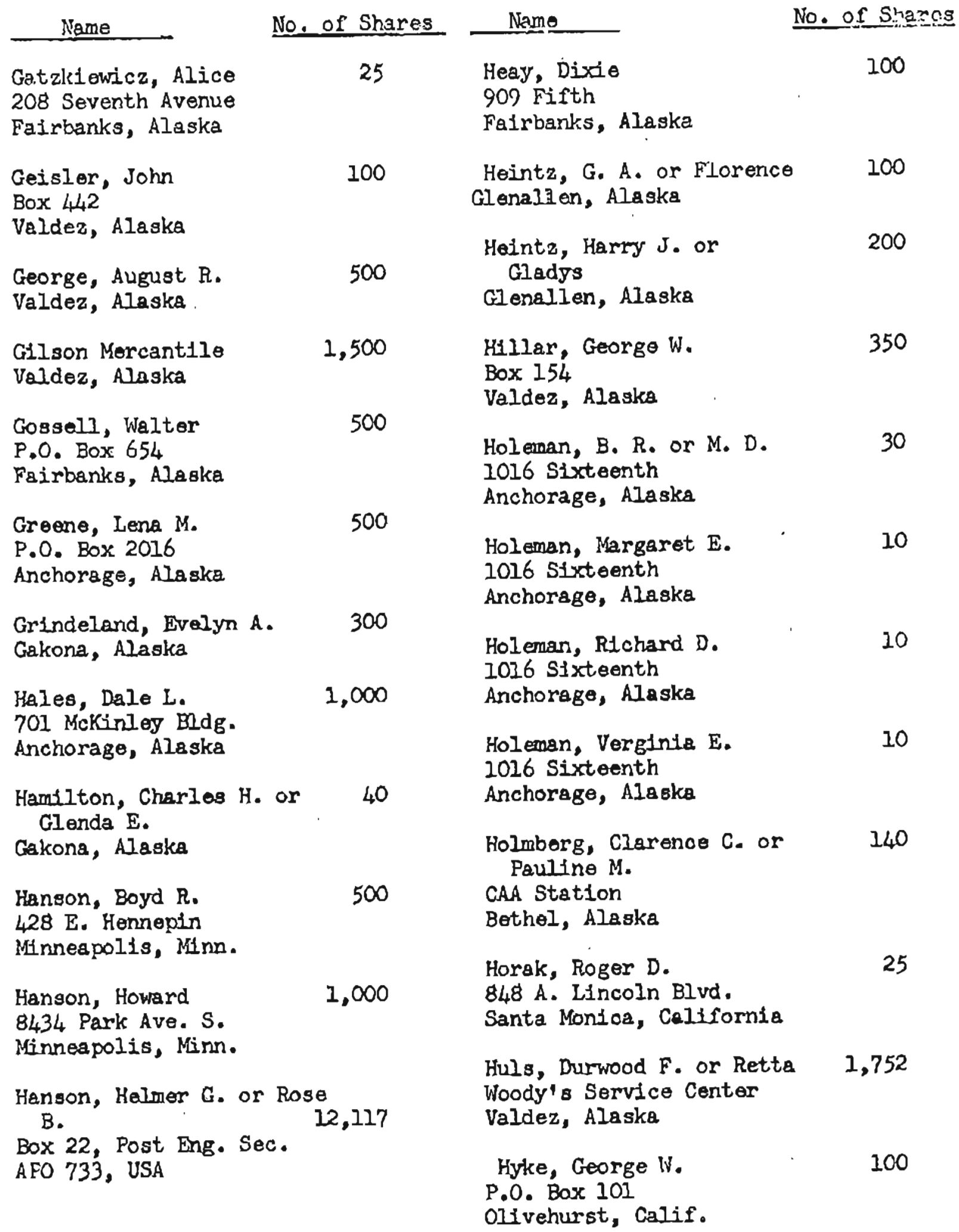


Name

No. of Shares

Hyke, Thomas E. or

10,454 Mary

Copper Center, Alsska

Jeasen, E. F。

Jessen"s Weekly

Box 970

Faírbanks, Alaska

Johnson, Owen P.

Valder, Alaska

Jones, Homer W. or

Marion $R$.

Copper Center, Alaska

Jones, Leo $M$.

200

Copper Center, Alaska

Joslyn, George C.

Valdoz, Alaska

Kedney, Fred $S$.

1,655

1,000

1,000

4225 E. Iake Harriet Blvd.

Minneapolis, Minn.

Kelleher, John or Ora 1,000 9106 Dalberg St.

Bellflower, Calif.

Kelsey, John T.

500

Valdez, Alaska

Kelsey, Robert D.

Valdez, Alaska

Kise, Donald W.

4.7, 0 Reiland Lane

St. Palil, Minn.

Kissell, Kenneth

Gakona, Alaska

Krause, William J. or Nellie B.

Gakona, Alaska

500

1,000

1,250

500
Name

No. of Sheres

Kvalvík, Henery or

200

Mary

Glenallen, Alaska

Kyle, Hillis

13,702

Big. Delta, Alaska

Lappl, Arthur J.

500

Box 440

Anchorage, Alaske

Langberg, Morris M. or 1,000 Constance P.

Box 384, Route 1

Stenwood, Washington

Lanstra, Mr. or Mrs.

100 Elmer A.

Southern Avenue, Aurora Subdivision

Fairbanks, Alaska

Lowy, George or Rose

200

Tiekel Iodge

Richardson - Alaska

Iunden, Jack

100

Box 3008

Anchorage, Alaska

Lundquist, Roger S.

500

1200 Bliss Lane

Minneapolis 20, Minn.

Lunsford, W. L.

250

Copper Center, Alsska

6,600

Major, Willtam L.

No. 4 Eleanor

Pairbanks, Alaska

Marinell, M. J. or Lee 500

Box 763

Fairbanks, Alaska

McCrary, Nelson J. or Mary 200

Copper Center, Alaska 
Name

No. of Shares

McKechnie, Norman D.

2,000

c/o Burgess Constmuc-

tion Company

Fairbanks, Alaska

Meleod, Bruce B. or

200

Pystie

Mile 164, Glenn Highway

Palmer, Alaska

McMahan, Cleo

1,000

Gakona, Alaska

Mehler, John S.

Box 1058

College, Alaska

Newhorter, Walter $F$.

USA CWM School

Ft. Greely, Alaska

Mitchell, Essie Lee

Glenallen, Alaska

Moore, Jack and Henra

Gekona, Alaska

6.950

Mowrey, Harry D.

Box 2996

Fairbanks, Alaska

Nelson, Joel R. or

Iillian $\mathrm{K}$.

Box 65

Fairbanks, Alaska

Nelson, John Lee or

Eilsie $K$.

Box 65

Fajrbanks, Alaska

Parrott, Connie G.

Hq. Sqd. Box 148

5060th Air Base Wing

Ladd Air Force Rase, Alaska

Peterson, Jerome J. 6201 Second Ave. S.

Mínneapolis, MInn.

20

50

106

200

100

100
Name

No. of Shareg

Parginger, Jim A.

500

Log Cabin Inn

Tok Highway, Alaska

Pettyjohn, D. W.

1,000

1100 Fenn.

Boulder, Colorado

Pettyjohn, F. S.

42,000

Gakona, Alaska

PettyJohn, Helen M. 13,900

Gakona, Alaska

Phillips Corporation

500

2409 Glenwood

Anchorage, Alaska

Pickett, Gerald A. Sr. 600 or Ira $\mathrm{L}$.

5972 Rainier Ave.

Seattle 18, Washington

Pittenger, Robert C. 2,000

c/o Box 1070

Fairbanks, Alaska

Renk, Albert E.

1,650

1902 Sunrise Drive

Anchorage, Alaska.

Radasch, Paul E. or

200 Anns $\mathrm{K}$.

Copper Center, Alaska

Ryan, Peter

500

Glenellen, Alaska

Sabottke, Iaure

1,000

725 Second Ave.

Fairbanks, Alaska

Schlader, Richard H. 200

8500 0akland

Minneapolis, Minn.

Severance, Marjorie

20

Box 1245

Fairbanks, Alaska 
Name

Shaunce, Leonard

647 Ninth

Fairbanks, Alaska

Simons, Mr. or Mrs. Arthur $\mathrm{M}$.

3901 Grimes Lane

ifinneapolıs, Minn.

Simons, Irr. or Mrg. 1,000 John $\mathrm{H}$.

600 N. Lilac Drive

Minneapolis, Minn.

Sipes, Frank

U.S. Navr - Pacific Fleet

10

Sipes, Johm or Willa Mae 1,000

Big Delta, Alaska

Sipes, John Wesley Jr. $\quad 100$ or Ireno

Big Delta, Alaska

Slocum, Hekie Sue

803 East 12th Ave.

Anchorage, Alaska

Smith, Gordon $C$.

c/o Fed. Electric, Box 432

Ft. Yukon, Alaska

Smith, harry $S$.

Glenallen, Alaska

200

Smith, Leonard E. or

1,500 Arlene

Box 12

Valciez, Alaska

Smith, Ray or Verginia

Valdez, Alaska

300

Smith, Richard F。 400 Ewing Ave. S.

Minneapolis, Minn.

Sodergren, Dr. K. A. 901 - 23rd Ave., N.E. Minneapol1s 18, Minn.
Name

Spence, W. E. or Clyda Mae

c/O T. E. Hyke

Copper Center, Aleska

Spurgin, Charles D. or 2,500 VIvian

Gakona, Alaska

St. Amand, Loren

100

Valdez, Alaska

Steele, Donald

2,000

709 Fleth

Fairbenks, Alaska

Stefeni, D. F.

100

Box 436

Fairbanks, Alaska

Stevens, Edwin

Glonallen, Alaska

1,000

Stewart, Claude or

200

Bertha C.

Copper Center, Alaska

StIth Motors

Valdez, Alaska

2,623

Shadburn, Claudo

200

Delta Junction, Alaska

Stripling, Iattie $W_{\text {. }}$

560

Gakona, Alaska

Taro, John J. or

10 Mary C.

509 Iarey

Fairbanks, Alaska

Tatje, Fred W.

Glenallen, Alaska

100

100
Taylor, Tryphena

Gakona, Alaska

500

1,000

Theisen, Thomas $E$. Delta Junction, Alaska 


\section{Name}

Therriault, Eli

Box 165

Charlo, Montana

Therriault, Hector

Box 2001

Faírbanks, Alaska

Thompson, Darrell

Fairbonks, Alaska

Torberg, Charles J.

640 Fourth st., N.E.

Minneapolis, Minn.

Uelrick, Sula

722 Ninth Ave.

Seattle, Washington

Walters, Benedict J.

3625 Elmo Iane

Hopkins, Minn.

Webb, Janes

Copper Center, Alaska

Webb, Mrs. Louise

Copper Center, Alaska

Wells, illroy Philip

Box 6II - Route 1

North Bend, Washington

Wells, Frederick M. or 1,000 Lee $M$.

Gakona, Alaska

Wells, Mex H.

Wells Commercial Company

Valdez, Alaska

Wel1s, Ricki

Gakona, Alaska

Whalen; John Bernard or Mary E.

Valdez, Alaska
No. of Shares Name

12,292

1,500

725

1,000

1,000

200

200

300

250

200

10

500
Whalen, Merie A. or Mary E.

Valdez, Alaska

Whalen, William J. or Mary E.

Valdez, Alaska

White, Clare

Palmer, Aleska

White, Paul

Palmer, Alaska

White, Mr. or Mrs. John

Palmer, Alaska

Williams, Jerry Edward

Box 23

Dockton, Washington

Williams, Jimmie Arthur

Box 23

Dockton, Washington

Williams, Vincent E. or WIIverna $R$.

Box 23

Dockton, Washington

Wilson, Roy R. or Josephine I.

Box 1826

Anchorage, Alaska

Wilson, Shirley Ann

Box 1826

Anchorage, Alaska

Windust, John

Paxsons Lodge, Alaska

1,500

Windust, Thomas R.

Paxsons Lodge, Alaske

Windust, Wh. L. or Doris. M.

Paxsons Lodge, Alaska
200

200

200

1,000

100

970

500

1,000

3,600

75 
Narne

No. of Shares Name

No. of Shares

Windust, Wizma $M$.

1,500

in.23. Sncdden

1000

Paxsons Lodge, Alaska

Fairbaths New Miner-

Wolfe, v. Eugene

300

WoG Koll

$100<$

Valdez, A.laska

Downey, Calvin J.

1,000

Box 101

Elmendorf A.F.B.

Alaska

Donovan, John Pat

400

Glenallen, Alaska

Ward, Ralph G.

200

Glenallen, Alaska

Weaver, Dr. Rlchard T. 300

1401 Lathrop St.

Fatrbanks, Alaska

Woodford, Howard F. or 500 Lolah

Woadford's Department Store

Veldez, Aleska

T. L. Robbing

Juneau, Alaska

\% B. P. R. 
$0 Y$

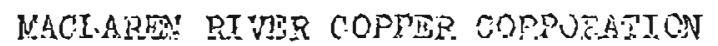

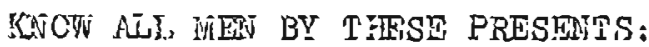

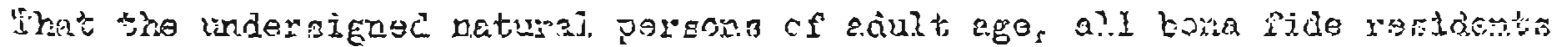

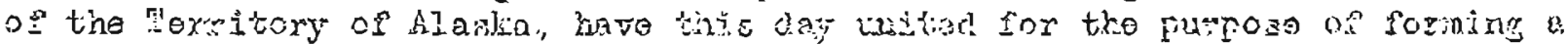

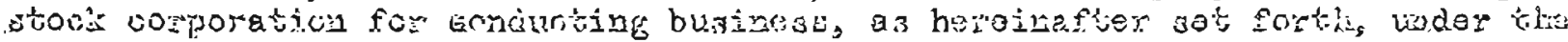

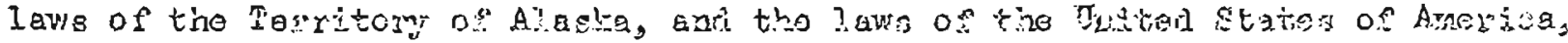

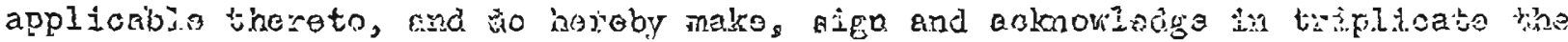
following Astioles of Tincompratica:

ARMTCLE I

IIng

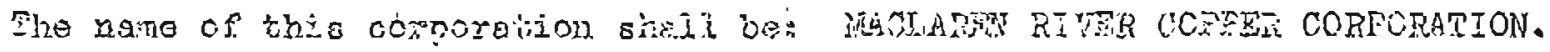
ARLTCLEII

Lisarangersers

The grindsal placo of business of this corporation shall be the Citgr of Fairbanks, Mlas stôs

ARTECLTSI

irinoses

This ceyporation te formed for the following purfosos:

(a) To acqulre, bug, Igase, owl, sell, mortgago and hypothacate mires, mining aisims, corl lands, inillsites, marufanturing sites, watir wights, and ouker real estate, and all goods and chattels of whateverer kind or character;

(3) To sonduct end anxy on mjuing ezploration and operations of every kind and chocecter withim the Territory of Alaske or elsewhers; and to sell the products thereor;

(o) In conetruct, buy, lease, own, operate, sell, morigage and hypothecate dredges, stean shoveis, hydraulic plants, pipe lines, flumes, ditches, dams, crushing plante, reduotion plazso, oawills, electric plants, railroads, tsamroads, telephone lines, and other equijinent and structures of whatsoever kind or charecter;

(d) To conduot and operate stores and morcantile establishiments for the use and convenlence of the corparation or for profit;

( $\theta$ To operate eloctric or other plants for the production, use and sale of powsr, heat and isight;

(f). To operate either public or private trancportation lines of any kind for tho use and benefit of the corporation or for profit; 
(g) To acquire, buy, own, sell and deal in stocics and bonds or $0 \%$ ber corporations or companios;

(h) And, generaily, to do and ferform each and everything that may be found necessery, proper or experient to ba corlo or performed in order to auble the corporation to cairy on ary of the ines of business herein specifìd

AFTICLE IV

Othe: rowars

In addition to the foregoing, said corposation shall have the following powe:s and authority, viz:

To do ady Iariful aut which is necessary end/or advisable to accomplish the vurposes of its incorioration. Without limiting or enlarging the of fect of this general grant of authority, it is heroby. spocifically provided that said corporation shall have oower:

(a) To have perpetual succession in its corporate name;

(b) To sue and be sued in its corporate name;

(o) To have ond use a common seal, and alter the same at pleasure;

(d) To elect such dizectors and officere, and appoint such agentis as its business requires, and to define their duties and six their compessation;

(e) To adopt and subsequently emend By-Laws, not inconsistent with tha lawis of the Dnitod States or the Teiritory of Alaslie, or with these Articles of Incorporation, determining the time and plaos of holding and the manner of calling and of condusting meetings of its stockholiers and diroctors, the mode of roting by proxy, the number, qualiflcations, powers, duties and terms of its officers and directors, ond detemining such other matters of aubstanco and procedure as may bo indicated for the proper oporation aud contro? of corporate a.foirsi

(i) To maino contracts, incur libuilities, and borrov money;

(s) To aoquire, hold and selj. shares of its own capital stock;

(h) To acquire, hold, sell, transfer, mortgage, pledge, or otherwise ¿ispose of bonds, stocks, securities or evidences of indebtedness, and while holding stock of other corporations to exeroise all the righto, pcwers and privileges of ownership, including the right to voto thareon:

(i) To acquire, hold, uso, manage, convey, lesce, mortgago, pleige or otherwise dispose of any other property, real or personal, deemed necessary or suitable to carry out its purpose.

\section{ART ICLE $V$}

Capital stock

The entire orpital stock of this corporaticn sinall be in the amount of One lifilion Dollars $(\$ 1,000,000,00)$ and shall be or one class only, to-yit: 
Common stock ditisible inl;o one million $(1,000,009)$ shares of a par vaius or One Deller (\$1.00) per share and issuable acoordingly. Each share shall have oqual weight for poting purposes at stockholders" meetinga, and stookholders: may pote their respectire sharos cumulatijoly.

Capital stock of this corponation ray be j.ssued by the corporation from time to timo for suoh oonsideration and under such terms as may be from time to time fixed by the Board of Directors of the corporation. This corporation may Issue any or all of ito shares of eapital stock in oonslderation of labor done, money paid, personal or real properiy, or intereat therein, or good-w1ll, and the judgment of its Board of Direoters respecting the oonsideration and the value thereof shall be finel and oonolusive in the absence of fraud; and the gtook so issued, the coneideration of which, os fixed by the Board of Directors, hes been fully paid, shall booose fully paid stook and subjeot to no further ouli or assessment.

\section{ARTICLE VI \\ Life of the Corporation.}

The perfod of the duration of the oorporation shall be unlimited.

\section{ARTICLE VII}

Indesteciness

The higheat amount of indebtedness or liability to whioh the corporation shall at any time be subject shall nots exceed the sin of Ong Million Dollars $(\$ 1,000,000.00)$ unleas tinis limit is lacraesed by the affirmative voto of twothtrds of tho outstanding stock.

\section{ARTICLT VII \\ Dirotore}

The affalis of the coiporatinn ghall be managed by a board of not leks thay three (3) nor more theis nino (9) of dilrectors, a majortty of whom sha? I soristituto a quorim for the transaction of business, the numba: of direotors to be detormined by the stockholders. Tho directors shatl elast one of their owa nombers President of the corporation and one vice-president, and shall also appoint a secretary ant a treagurer, oither from their pwn members or otherwise, it boing understood that the office of secratary and troasurer may be combinad. The dutios of seid officers shell be presortbed in the Ry-Lawa. The directors may also eppoint such other offlcers or agents as may be deomed nevessery to properly conduct the businegs of the sorporation. The namos and

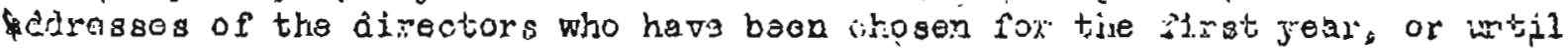

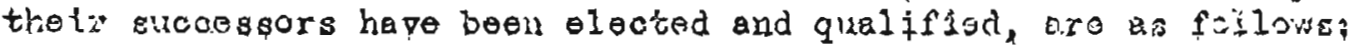

I. S, Fettyjohn, Jie, Fairtanks, Alaske

Howard Baylesi, Fár.banks, Alaskn

Warj. H. Belis? ine, Fairbaiks, Azasita

Subject always to By-Law made and adopted by the stockholders, the Eoard of Directors singll, when necoseary to expedite the condict of bupiness, hava power to make such supplementery By-Laws"as it "Ceems proper for the management of the affatrs of the corporation, and from time to time may alter, amend, or repeal auch sixplementary By-L.aws, but any By-inaws mado by the Board of Directors may bo eitered or repealed by the stockholders at any annual meeting, or any special meeting oalled for that purpose. 
ARTICLI IX

Stoobholdars' Meetings

The first mgeting of the stockholders of the corporation for the adoption of By.Laris, election of diroctors, eten, shall be hald at Fairbanks, Mlaska, or othei dosifnatod ploce on or about locembor first, with subagtieni mostings on tinat date asch yoar ihareafier.

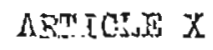

Axenciaes: 5

Those Artivies of lucorporation mav be anended whon authorized by a rote

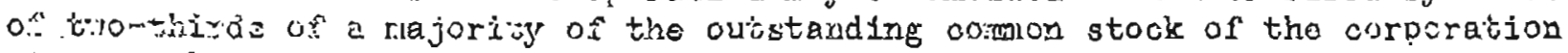
at a ragular mosing of tha stockholders or at a spesial meating called for that purcose, snd such amoncied Articles shall be execited and acknowledged by the Board of Directors, or a majority of them, and shall be filed and recorded in the same place and manne: os the original Articlos.

AFIICLEE XI

zacosporators

The names and places of residenno of the persons forming this corporation are as follows:

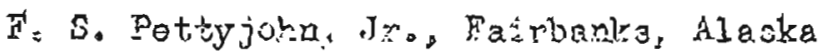

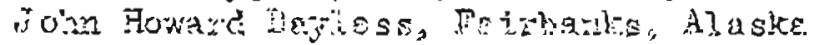

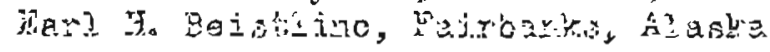

IN WITNESS WHEREF, said incorporators abore named have hereunto get


of Ootober, 1956

$$
\begin{aligned}
& \text { (Sigaed) I. S. Petrirohn, Jro (SEAT.) }
\end{aligned}
$$

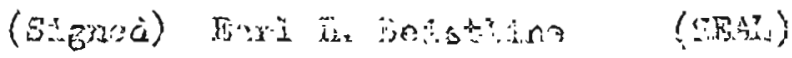

$$
\begin{aligned}
& \text { (Stimad) john Howaru niglose (SEAL) }
\end{aligned}
$$




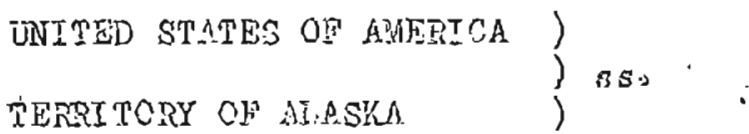

THIS CenTIFIES that on tiji.3 27ti, day of Qutobor, 1956, before ne, 2

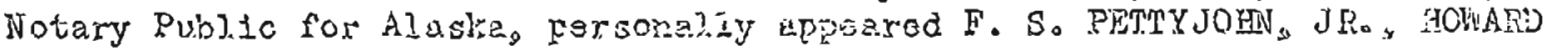
BAYLESS, AND EAPL H. BEXSTLINE, to ma koory to bo the identicaj porsuns

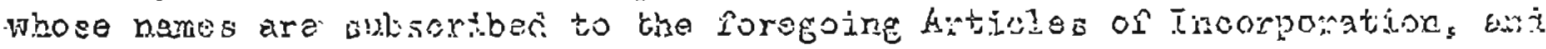

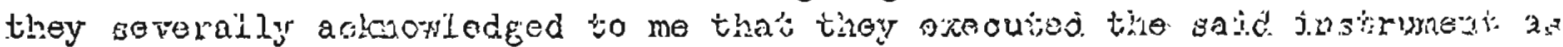

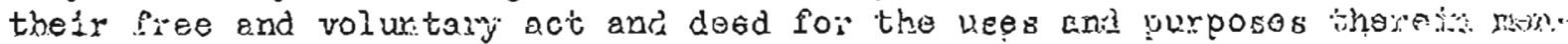
kionod

IN WITNESS VHERTOF $i$ have hereinto set my hand and affixed my notarlaed sear on the day and year in this ceatsilcate silst above writton.

\author{
(Sigived) Ralph Ja RIvers

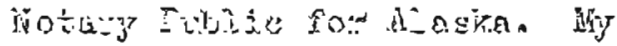

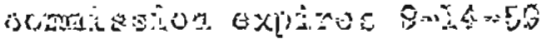

(notary Sos.) 
Vefices sinall be established for conducting tho affairs of the comporation (at such bima as the business thereo? reguiros) at somo sutable looztion in the Cisy or Fairbsuks, upon arrangenents nado by the snard of Elresto:s.

\section{IEI}

SIGNEFS. HEREOF"

It 13 understood and agreed that the temporary directora, al rtockioliess, shall siga these By-la ws in attestation that same have beon adopted by the majority of stoukholders at tho first etookhoicers" mooting. but other persons obtaining stook in this company will be bourd hereby willout sighing samo.

\section{I}

STOCKXOLDERE

(a) This'e shall bo one regulas mesting of the common stoolsboltor ennually for the elootion of tha Eoard or Diractors and for conduating such other businoss as may arise, to be held on tho sirst day of December of ogch year at Fairbanks. Witil ranpect to these mestings, notice shall be sent of the tims and place theroof in the form of a postiard, or otherwise, by depositing oamo in tho posi ossioe, 'drectod to the stockholciers respectivoly' at their las' known adaresa. os. not later then thisty days prior to the tims set for suoh meetingse

(i) Other stockrolders' ngetings, to be reforred to as apocial neetings, mey bo hold upor call by the President, or Board of Directors, acting through a majority of its members. With respect. to the meotings, adequate notice shall bo given as tho Board of Directors may decire, provided that such notice ehall state the pirsose, ox furposes, for which a spocial meoting is called.

(c) At least ono-tiniri of the common stock which has teen isolied must be represented at a stockholdons' nesting to constitute a quorum for the transaction of business, and aotion by stockholders will be based ch a majority voto of the stoek represented at the meet. ing. The Prasident of tho Board of Directors or somacno acting in ins stoad shell be the presiding officor at stoalholders mestings, and. tho Secratiasy of the Bogrd of Directors shall set as secretany for suoh meotings. 
(d) Every stockholder having a right to vote at a stockholders meetjing shall be entitled to vote in person or through written proxy subscribed to by the stockholder and bearing the name of the stockholder who is carrying such proxy and dated not more than thirty days prior to said meeting.

(e) Any stockholder may waive, in writing, any notice required horeunder.

\section{$\mathrm{V}$ \\ BOARD OF DIRFCTORS}

(a) A Board of not less than three (3) nor more than nine (9) Directors shall be chosen annually by the common stockholders, at their annual meeting, to manage the affairs of this corporation. Their term of office shall be one (1) year, or until their successors are elected and qualifiled. The procedure at these elections shall consist of first deciding the number of persons to serve as directors for the coming year and then nominating at least that nany stock.holders and the casting of ballots (showing the number of shares being voted) for the designated number of nominees of the voters choice, and, upon the tally being taken, the designated number of persons having the highest number of votes shall be elected.

(b) Vacancies on the Board of Directors, by reason of death, resignation on change of residence from Trairbenks or vicinity, shall be filled by the ranaining Directors choosing from among the corporation stockholders to fill the unexpired term.

(c) Reguiar meetings of the Board of Directors shall be held not less than once each calendar quarter at Fairbanks, at such time and at such particular place as the Board may determine.

(d) Special meetings of the Board mey be called by the President, or any two Directors, by giving not less than three days notice to each director. Uniess othermise indicated in the notice thereof, any and alz business mey be transacted at a special meeting.

(e) At any meeting with a quorum, held without the thirty deys notice, at which every Director is either present or has signed a waiver, any business may be transacted. Any Director may waive, in writing, any notice required nereunder.

(i) A quorum for the iransaction of business shall be a majorjty of the members of the Eoard and each Director, including the President, sizall have one vote. As to all. matters, the affirmative vote of at least a majority of the pirectors present shall bo necessary for the taking of any action.

(g) Business shall be transacted in such order as the Board may, from tinie to time, determine.

(h) The Presiden' of the Board shall be the presiding officer at all meetings, or in his absence, the Vice-President shall preside, but in the absence of both of them, such other Director as those oresent may designate. 
(1) Directcrs, as such, sheli not receive any stated salary for the 1: genvices, but, by resoiution of the Beard, a fixed ourn and expenses of attendw anco, if any, may bo allowed for attencence at each regulan or special negt-. ing of the Board; provided, that nothing herein contained shall be construed to preciude any Director from serving the corporation in any other capacity. and receiving compensation therefor.

\section{YI \\ OFFICERS}

Officers of the oorporation shall consist of the President, VicePresidenc, Secretary, and Treaslirer, electied by the Board of Directors, and such othe: soectal office?s, professional help or agents as may be appointed by tho Board of Dijectors.

(a) Oaly meminers of the Boart of Diractors shall be eligible for the office of ryestident. The President shell be the executive head of the corporaton unless an executive manager is employed.

(b) The same eligibility requirement applies to the office of VicePresident as for that of President. The Vice-Presideat ohall assist the President and bhall succeed him to fulfill his unexpired term in the event a vacsency oscus: au

(c) Ihe secretary neod not be a Director, but must be a stoskholier of the Corporation. The Secretary shall keap ninutes of Directors meetings asd stockholders meotings, have custody ô the records of the corporation, except as otherwise specified in these By-iaws or by the Directors, handle corras pondence, mail notices, etc. $\mathrm{His}_{\mathrm{s}}$ records shall be open to stockholders at all reasonable times. Should the Secretary not be a member of the Board of $D_{i}$ rectors, he or she may be preesnt at Directors meetings, but shall have no vota.

(1) The Treasurer need not bo a Director, but musi bo a stockinolder of the curporation. The Treasurer shall receive and koep all funds and deposith seme in a baluk or in suoh other dopository, or depositories, as may be dosig neted by the Board of Directors, end such deposits shall be made in the name of the corporation. He shall also have custody of bills, notes, mortgages, bonds and similar property belonging to the corpcration, and shall do with the same as may be ordered by the Board of Directors. He shall keop such financial accounts as may be required, and at the expiration of his term of office, shall turn over to his successor, or to the Board of Directors, all property, books, papers and money of the corporation in his hands. The secretacy's records shell be open to stockholoers at all reasonable times.

(e) Tine Directors nay nerge the offices of Secretary and Treasuror, so that both pcsitions may be held by one person.

(f) Salaries or other sompenation of officers and agents of the corporation shall be allowed cnly upon resolution of the Board of Diroctors, and the amount thereof fixsd in such resolution. Part-isme servioes may bo authoriad. for part-time pay.

(f) All officers and Egents appointed or employed by the Board of Directors shall be sulject to removal at any timo by the affirmative vote of a majority of the whole Board. 
CORPORATE SEAL

(a) The corporate seal of the corporation shall consist of two concentric circles, betweon which is the name of the corporation, and in the conter shall the inscribed. "Corporate Seal, 1956"t, and the words "Torritory of. Alaska" shaij. appear on the botiom of the seal between the two concentric ciscles, and suoh seal, as impressed on the margin hereof, is heroby adopted as the seal of this corporation.

(b) The Board of Directors shall determine by resolvtion which documents or types of documents shall require the affixing of the corporato sealu

VIIT

DI SBURSENENTS

Digbursements of corporate funds shall be only by checls sigaed by the Treasurei, and should the Board of Directors so roquire, covatersigned by the Presidert. or other officer authorized by the Boare of Directors to so act in the Presidont's behalf.

\section{IX}

FARTICUIAR PONERS OF DTRECTORS

In addition to the powers and a thority by these Byal.aws especialiy confersed upon it, the Board of Directors may exercise all corporation powers and do ai l lawful acts and things, except as required to be done through action of the stockholders by statutory provision, the Articles of Incorporation, or by these ByOLaws. Such powers shall include:

(a) Authority to lend and borrow money and to enter into contracis in the regular ccurse of business, and to enter into contracts of purchase ard salo of real property, or personel property, to issue cromjscory notes, to noxgágo and hypothecate real and personal property, and to transfer property aoquired by the corporation on appropriate terms and conditions, as mey be necess ary or actisable to accomplieh tho purposes for which this corporation is formed. owed to the corporation.

(b) Authority to require and accept security for moneys owed or to be

(a) Bond of Officers or Agents: The Board of Directors may, by resow lution, require any and all executive officers or agents to give a bond to the corporation with sufficjent sureties, conditioned upon the faithful percormance of the ditles of their respective offices, and such other conditions as may, from time to time, be required by the Board of Directors.

(3) Delegation of Duties: The Board of Directors, by affirmativo vote of a majority of the extire Board, may delegate for the tire being the powers or duties of any officer of the corporation, in case of his absence or for any other reason, to any other officer, or to any Director. 
(a) Stock Certificates. Svery stockhoider shail be entitled to a cerm tifleate or certificates of capital stock of the oorporation in such form as mey be proscribed by the Board of Dirootors, duly numbered and sealed with the corporate seal of the corporation and setting forth the number and kind of shares. Such certiflcates shall be signed by the Prosident or Vico-Presideat and by the Searetary.

(b) Transfer of Stock. Shares of stock may be transferred by cieilvery of the certifioate accoupanied by either an assignment in wititing on the back of the certificate or by a writter powew of attorney to seli, assign and transter. the same on the books of the corporation, sigxed by the person appearing by the certificate to bo the owner of the shares represented thareby, logether with all zecesary federal and territorial transfer tax stamps affixed, anci shall be tranafarred on the books of the corporation upon surreader thereof so assilgned or endorsed. The porson registerod on the books of the corporation as the omen of any shares of stock shall be entitiled to ail the rights of ovaen ship with sespect to such shares. It shall be the duty of every stocklolder to rotipy the corporation of his post-opfice address.

(a) Trensfer Books. The transfer books of the stock of the corporation ray be ciosed $\hat{\text { for }}$ such period, not exceeding forty (40) days, in anticlpation of scockinolders meetings as the Board of Directors may decemina. In lieu of closing the transfer books, the Board of Directors may fix a day not more thay. rorty (40) deys prior to the day of holding any metings of stockholders as the day $a \mathrm{~s}$ of which stockholders entitled to notice of aud to vote at such meeting shall be determined; and only stockholders of reoord on such days sholl be entitied to notice of or to vote at such meting.

(d) Loss of Certificates. In case of the loss, nutilation or destruction of a cextificate of stock, a duplicate oertificate may be is bued upon such terms as the Boare of Directors shall presoribe.

(o) St ook Subseriptions. Subscriptions to capital stock shall be paid in rull, unlesis otherwige authorized by the Board of Directors, and shall be paid in lawiful noney, or in real or personal property, or labor perfornece

\section{$X T$ ALENDLENTS}

These By-Law's may be amended by an affirmative vote of the majoriby of the stockholders at any regular or special stookholders meeting.

We, the undersigned, as of this date, being all stockholders and the nelibers of the temporary Boerd of Dinectors, hereby exccute the foregoing Bur-ars in attestation or their acoption by the stookholders.

Iiv FIINESS MHEREOF, we have hereunto set our hands and reals this day of $\times 195$

$$
\begin{array}{lll}
\text { (signed) F. S. Pettyjohr. Jno } & \text { (SEAL) } \\
\text { (signed) Earl H. beistiline } & \text { (SEAL) } \\
\text { (signed) John Howarz Bayless } & \text { (SEAL) }
\end{array}
$$


INVENTORY CF EQUT FAENT

August i, 1957

Description

F.O.B.

PRICE

Gardner-Danver 600 CFM Comp (Portable - powered wi th Modi-D 13000 Cat Diesel)

Soettlo

細 14,38600

ECO Mod-12-B Mucking Hachine set for $24^{\prime \prime}$ Gaugo Rails

Seatile

$3.87 \pm .00$

1 MOD D-JTA-J oy Drill Jumbo w/2" DJA JOY Drill Jibs and 2 TM 350 Joy Air Drill Machine s/L W-6 Auto Feed

(6' Bed) Using 8' $\times 1$ 1 Stenl

Seattle

$5,670,00$

2 only ćl cu. ft. ond dump ore cars, Hod Coeur p'Alene (a) 300.00

Spattle

600,00

1 Rlod 55A Chicago Puoumatio Diamond Drill complete with $300^{3}$ of $5^{3}$ rod ex air rod pulley, 6' bar with mouriting and tools

Soattlo

$2,421.00$

Black and Decker $3 / 4$ hp $220 \mathrm{~V} 3$ ph, Grinder with $j$ ig for Timken Carbide bits

Seatt?e

320,00

5 hp Air Mo:jor Drivo 3 KVA Genorator for 110V-i ph aud $220 \mathrm{~V} 3$ ph with panel

Seattio

600,00

1 lífod, SK 7645 Sullivan single drum air hoist

Seattle

350,00

1 only $30^{\prime} \times 60^{\prime}$ High Steel Butler Bldg. with $18^{\prime} \times 9^{r}$ door - heavy dutiy shop

Mine

$\Sigma 0,000.00$

1 only i2l $x$ 40' Butler Steel Blog. insulated washroom, store room, messhall, and kitchen, complete

Mine

$10,000.00$

2 only $14^{4}$; $30^{8}$ Frame Bunk Houses with oil heaters and bunks @ 3,600

Mine

$7,200,00$

1 only 1954 Wiliys Jeep with cab and front. mt. winch (10) $\$ 2,88.00$

Trairbanks $\quad 1,500,00$

1 used GivC (Ariny) 6 × 6 durnp truck with front mit. winch ( 10 new tires and tubes -50 miles, and new motorl.

Mino

$2,600,00$

1 only hervy duty front boom working of' winch sor GMC $6 \times 6$

Mine

500.00

only used 19-ton Athey vagor :

Feirtanks

600.00

I oniy joy Mod 1-16 Fan $w / 1$ hp $220 \mathrm{~V}$ Elec. drivo

Soattle

378.00

I only igs3 Interrational ㄱoz Panel

Fairbaaks

$1,200,00$

Mise. now and used drill steel l-ini sine

with oarbide bito

Mine

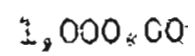

Wigco hand tools, portable tools, wronches, oto. at tipplo shop

Mine

$2,000.00$ 


\section{Description}

1,100 rt. of $24^{\prime \prime}$ mine rails and sattings

Steel 60' size air roceiver

Jack hamer, $R$ and $I, 3 / 4^{\prime \prime}$

I Jaouzzi, I hp Model C56J2A5, water pump

4 now emery wheols, $8 \times 1 \times 5 / 8$, Black \& Decker

50 doarse thread $5 / 8^{\prime \prime}$ carbon treated belts

Misc. eloctrical fixtures

5 fire extinguishers, carbon

12 new jockhamer steels $3 / 4^{\prime \prime}, 3-\frac{1}{7}$ st lengths

1 sump pump, $R$ \& I

13 new joolchammer steels, 3/4", $7 \mathrm{ft}$. Iengths

1,500 rt. misc electric wiring and sockets

$320 \mathrm{ft}$ - alr and water hose

I Joy, Class $\pi-I$, spotifigt generator

$300 \mathrm{ft}$. of $2-3 / 4^{\prime \prime}$ air Iine, corplete with plgs (Thor)

1,200 ft. new 1-1/4" water l lae pipe and fittings

$100 \mathrm{ft} .3 / 4^{\text {n" water }} \mathrm{line}$ pipe and fittings

$100 \mathrm{ft}$. radío antema poles, galvanized, set up, with antenna

7 only $12 \times 24$ welded angle 1ron road arag (float) for winter truck road and airport maintemanoe

60 ft. $2-^{\frac{1}{5}}{ }^{n}$ water line pipe and fittings

$60 \mathrm{ft}$. $2^{\prime \prime}$ water line plpo and fittings

120 ft. 1-7 w water line pipo and fittings

1 Hodel NGS-SF, Pacifio Plumbing Co., Turbine Pump with base and coupling - LBiman Air Motor. (new)

with 1 Cash-Acme Typo E regulator.

1 worming house, $8 \times 10$, with colemen stove

1 reil, bender, $R$ \& $I$

\begin{tabular}{|c|c|}
\hline$F .0, B_{0}$ & Price \\
\hline Mine & $\$ 1,200,00$ \\
\hline Mine & 500.00 \\
\hline Wine & 250.00 \\
\hline Mine & 300.00 \\
\hline Mine & 175.00 \\
\hline Mine & 50.00 \\
\hline $\operatorname{Min} \theta$ & 100.00 \\
\hline Mino & 250.00 \\
\hline Mine & 65.00 \\
\hline Mine & 275,00 \\
\hline Mino & 110.00 \\
\hline Giné & 85.60 \\
\hline Mine & 200.00 \\
\hline Mine & 400.00 \\
\hline Mine & 250,00 \\
\hline Míne & 600.00 \\
\hline$M \ln \theta$ & 20,00 \\
\hline Mine & 300.00 \\
\hline Mine & $2,500.00$ \\
\hline Mine & 100.00 \\
\hline Min $\theta$ & 80,00 \\
\hline Mine & 100.00 \\
\hline Mine & 386.00 \\
\hline Mine & 200,00 \\
\hline Mine & 60.00 \\
\hline
\end{tabular}




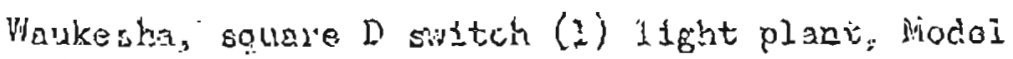
Hoder rotung

1 heary duty tralloi, for acotynere torch w/scmplete acoly ore welding ard cuting outfit

$150 \mathrm{fic} 3 / \mathrm{s}^{\prime \prime}$ marile rove

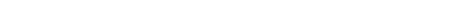

lito flio J." mansla rope

1 Buigit, 1wion shain hoist

J. pipo vice, cltte:, die, d reamer - net -r Rision Model o $5-R$

1 Hobarti Bros, eloc. are mistor, 2ypa T-13 6-5-3, completis

Wisc. pipe fltting and stoel, galvantpec

$1+\tan 2:$

I aleotro-mode, ais heater, Model biv-50A. Type 32590

Chromalox, eloo. Heating element, Hodel Ellato

$1 \mathrm{KIm}$, hot-start

2 O-L, îigs, I'hor.

20 oable oilamps, $3 / 4^{t r}-1^{\prime \prime}$ oable

1 overhaul kit for Waukesha light plant

Míco veiticlo enc lor cirains

1 biontiorcis

$\leq 6$-roit battiariss

2. Exide bettery shergar

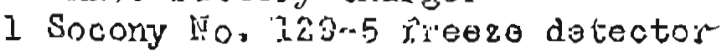

J. Milwelliceo; sililis saw

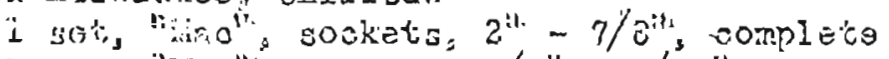

1 ist, "kila", noctets, $1 / 4^{\prime \prime}-7 / 1^{\prime \prime}$, complete

Hisc. tools, er,u, braces, bits, wrenchos, otc.

3. Dolco, weach ginc $\mathrm{r}$, liodel A-1057, 1/3 hp, IIV

1 35i, Chexlas Pakkar beach vico

1 rulanizing tirs "spair seti

100 pids, 8-D nails

50 pis.s 6-0 aeiis

110 pds., 18-comon nails

100 pres, 40 -oommon neils

$5 \mathrm{misc}$ pick ars tre haiadles, now

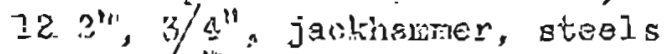

$3 T^{\prime}, 3 / 4^{1,2}$, hackhamner, ateols

i.5 panes glass, $15^{\circ 1} \times 18^{\prime \prime}$

3. pares glass; 2$]^{21} \times 51^{\prime \prime}$

2 cerbonic Gac. Co., fire ext.

$21 / 2$ gals. linseed ail 


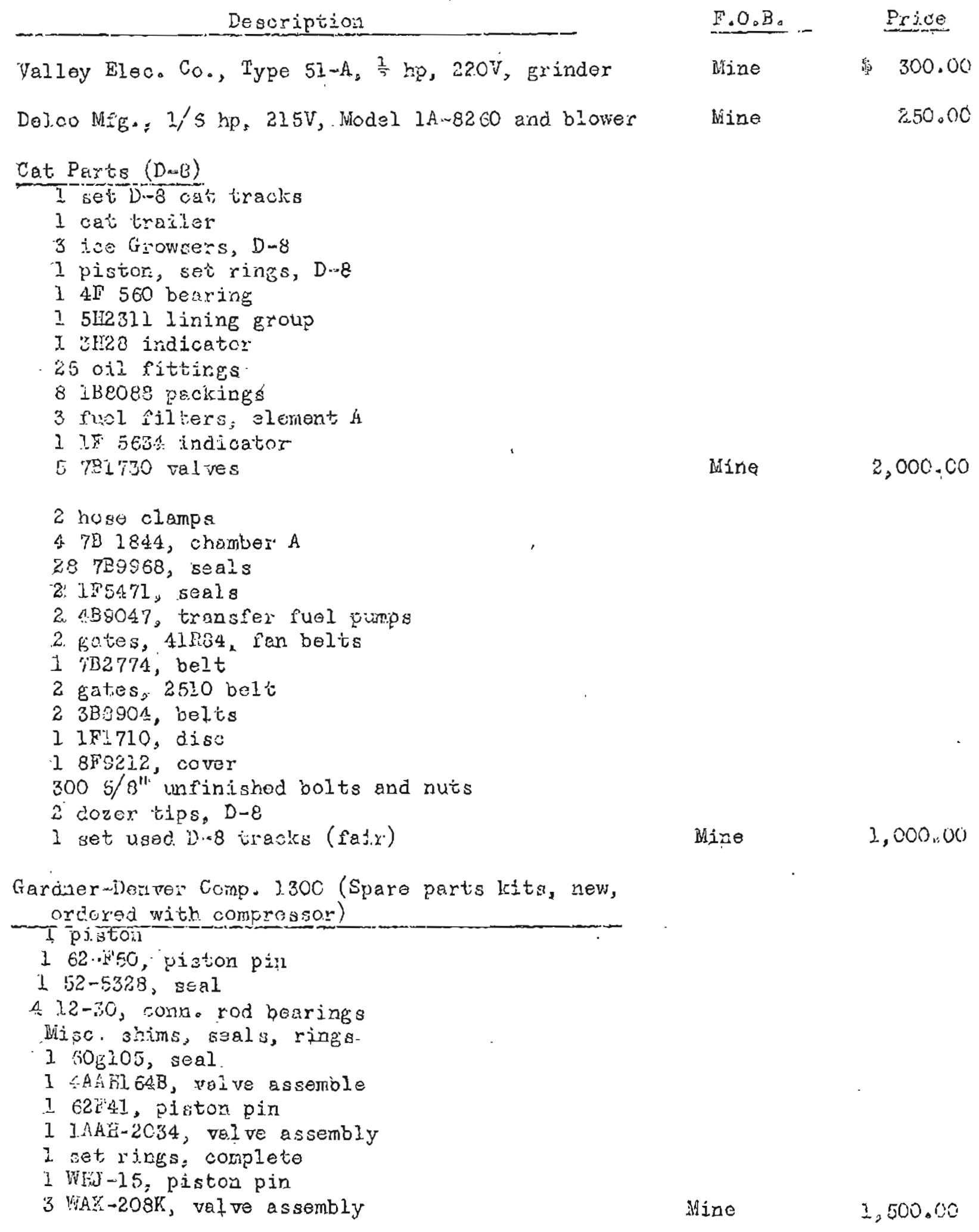

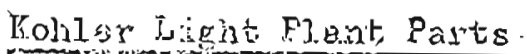
1 hae gasket
1 suoj. puno repain kit
1 set rings
1 pistoin
1 Bandix inition, 10-70169

Hino

100,00 
F.O.B.

bine

Bin, misc. bolts, auts, seals, kits, etc. for D -8 Cat

Items

5 Tinken, 1-7/8" carbide ingerts, H thread bits

so Tinken, $1-\frac{3}{3}$ it steel bits, $H$ thread

-24 Timken, 2- $\frac{\text { Tlt }}{4}$ carbide inserts, D thread hits

50 Timicen, 1-?/8"' steel bits, D thread

I AX oore barrel, Christonsen, 5 ft. length

1 AX oore barrel. Christensen, $10 \mathrm{ft}$. length

I reqmer, dienond, AX, Christenson

1 pilot bit, dianond, $A X, C h r i s t e n s e n$

6 diamond bits, AX, Christengen

30 pds $6 / 32$ wolding roa

30 pds $3 / 16$ welding rod

$30 \mathrm{pds} 3 / 32$ welding rod

2 hydraulio jacks

Prics

100.00

Total of Equipment
Mine $\quad 3,600.00$

Total of Supplies

$-97,527.00$ 
LIST OH SUPATIES



OMT MTE

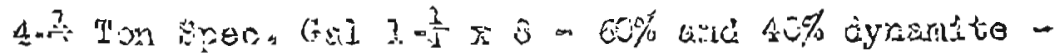
o

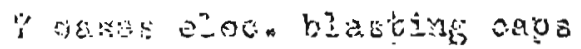

$4 \%, 0,00$

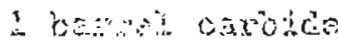

10.00

6 minais" holmotis, Maswi, tyeg $\mathrm{T}$

30.50

1 barrel driijule

seco

5A.5C-gen. bars9!3, diese]. ruet

$I, 350.30$

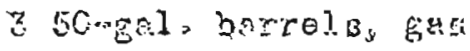

75.00

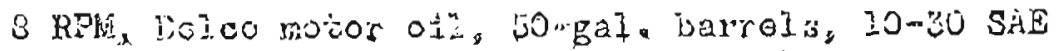

800.09

f: 2" $2^{n} \times 10^{\prime \prime} \times 16^{\prime}$ lumbor plunks

250,00

T'teins

Tu ptye Chevron stersting filuid

I bej. Loosuin-til

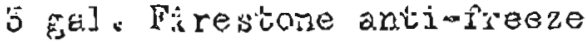

10 trl. Aviation lio. 1 aviation greace

e j-gal. cans RM groase

5 geil. hoavi duty brako fluid, hydraulic

$300: 00$

Groseries

1., 000.00

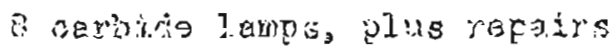

20.00

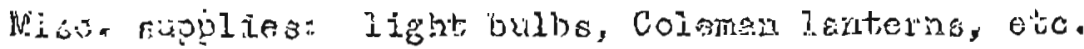

.200 .00

Totad. 3upp?ios

9.050 .00

Desiverad in Octoiser. 1957:

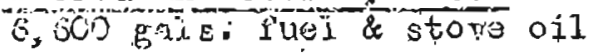

Ojis grease, eto.

$\therefore, 250,00$

250.00

100,00

7000 ft. timbers

$3,000,00$

Grosertes

500,00

Misc. parts

$-\frac{1,000,00}{7.00,00}$

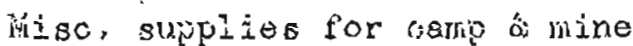

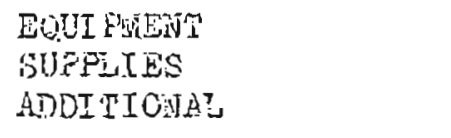

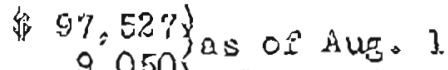
9.050 Jalivered in act. 19+2

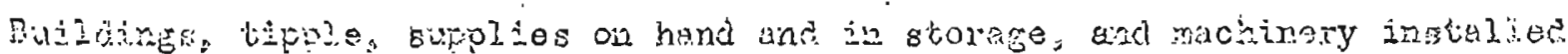

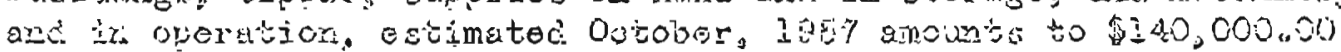





tond os: $\&$ pes cent copper oro reduced to 8 tons of 36 per cent oopper oon:enting

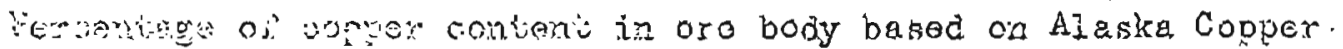

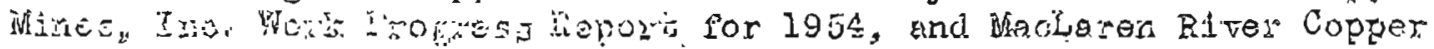
- Corforation sariciling arid assaying report for 1957 .

Recopery of copper taseü on Denver Equitiment Company tests, and U.S. Eurean of Mined ropurts.

Shipeing contis baseo on Alssia Freight Lines.

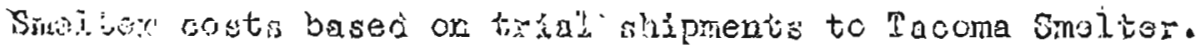

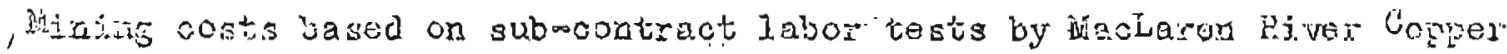
Coriporetion.

Miling costs based on tosts aun by the Denter Equjpment vompary. Oxerhoad based on líadnien River Goper Corporation got recocds. Wrice of coppor besed on present market, and Engineering and Mining Journal forncastus.

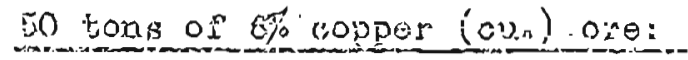

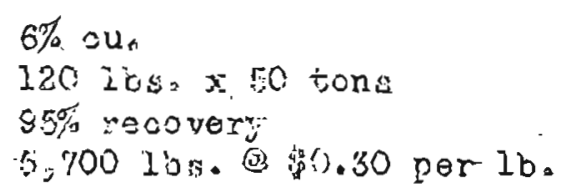

12,0 lbs. cu. per ton 6,000130 a chio $5,7001 \mathrm{bs}$. cli. $11, r=0.00$ recovery ovory 24 ins 


$$
x \Leftrightarrow
$$

Sindes (mar tor)

T.B.

$\$ 2.30$

Powcer \& onpis

400

Tiansal ic oli

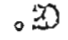

Seshresty depreciation

.20

insichobal. eurghion

$-20$

is

$205 \quad$ ind 25

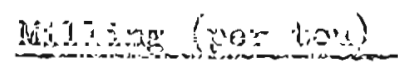

I.ebor

De?ser \& oj?

lusinery delizectation

Lríling suppliss

Commessary (per icy)

Hos: quertejrs, cook

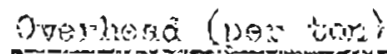

Supervisjon, enfilusing, orfice

S3LE wo've?

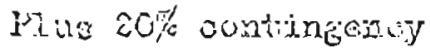

Sotal per tion

(40)
$\$ 2.50$

.30

$\therefore 4 Q$

$-0.50 \quad \$ 2.70$

1.00

$\$ 20.00$

Shigrint:

50 tions or 6\% cu. - 6,000 lbs. cu.

$93 \%$ recovery $-5,700$ los a clie

8 tons of $35 \%$ an. 5,700 1bs. owa

8 tons shipping (3) $\$ 40,00$

$\$ 320,00$

8 tons smeltering 12.120

39.20.

sub-tota?

\$ 19.20

Plus $2 r 3 \%$ cortingency

83.40

$\$ 502.60$

TONAl costs per day per 50 tone

931.00

Returns

Costs

NET PIS DAY

per 50 bons
$\$ 1,710.00$

3.3 .60

$773=40$ 


$$
-3 / 41
$$

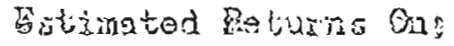

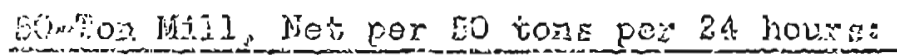

\begin{tabular}{|c|c|}
\hline$A 0 \%$ ou, & 0.00 \\
\hline $500 \% \quad 0120$ & $35 \Delta 600$ \\
\hline$\varepsilon_{0} 0 \%$ ou. & $76, \leqslant 0$ \\
\hline $7.0 \%$ sua & $1,041,00$ \\
\hline
\end{tabular}

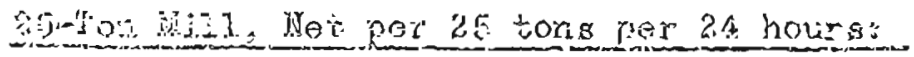

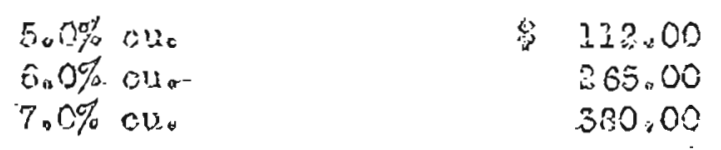


Goological Survej.

Wastington 25, D。i.

Goutlemea:

PJesse forward one copy of "Geologicel sirvey Ciroular 332" -

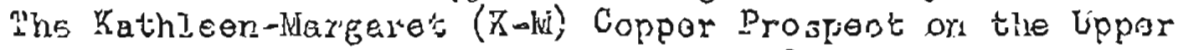


Saumciers.

It is notod that copies of this Circular $3 \ddot{2} 2$ are free upon ipclication. However. if this offer is now closed und a feo is requirad, ploaso notisy me.

$$
\text { Vory truiy yours. }
$$




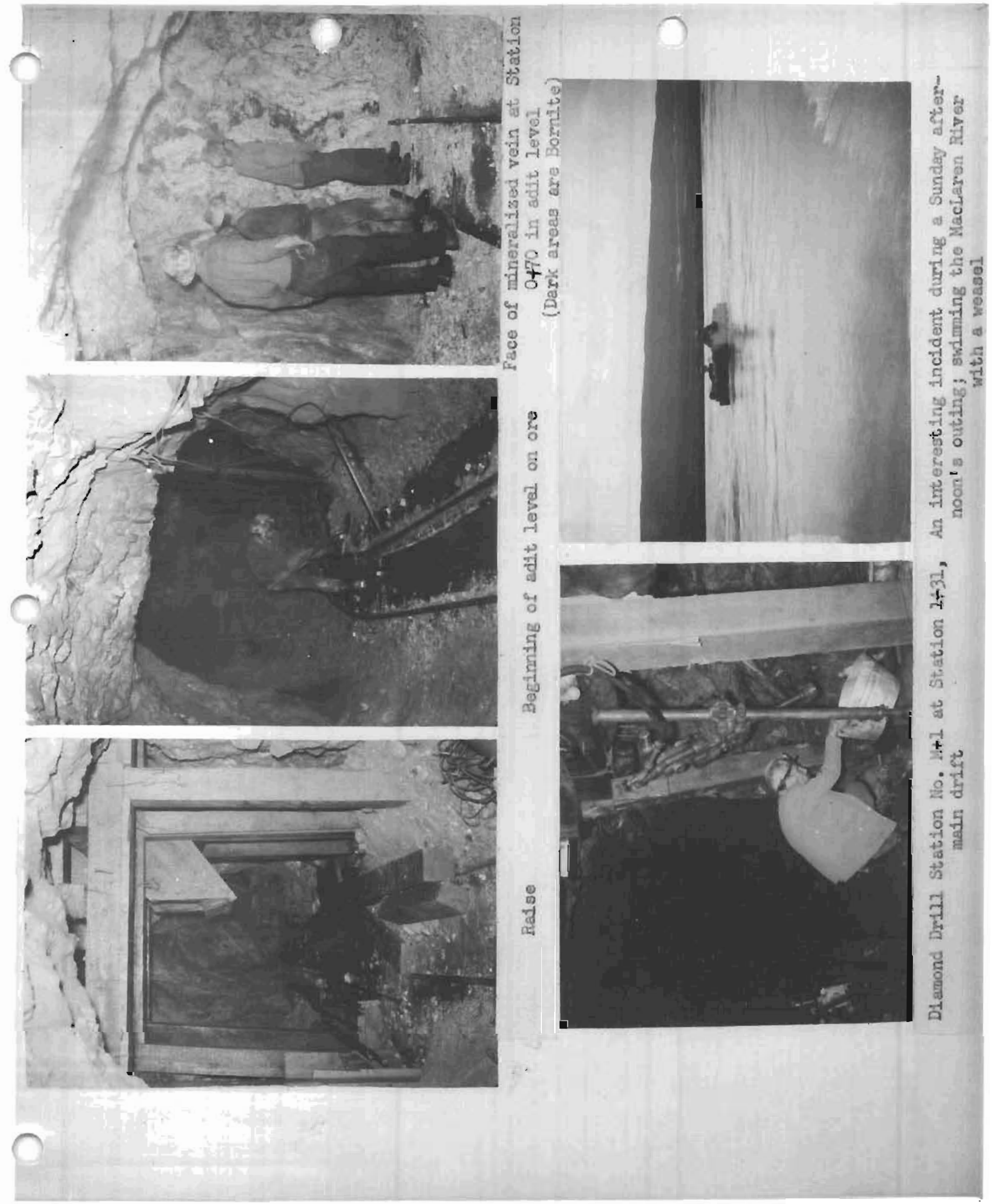



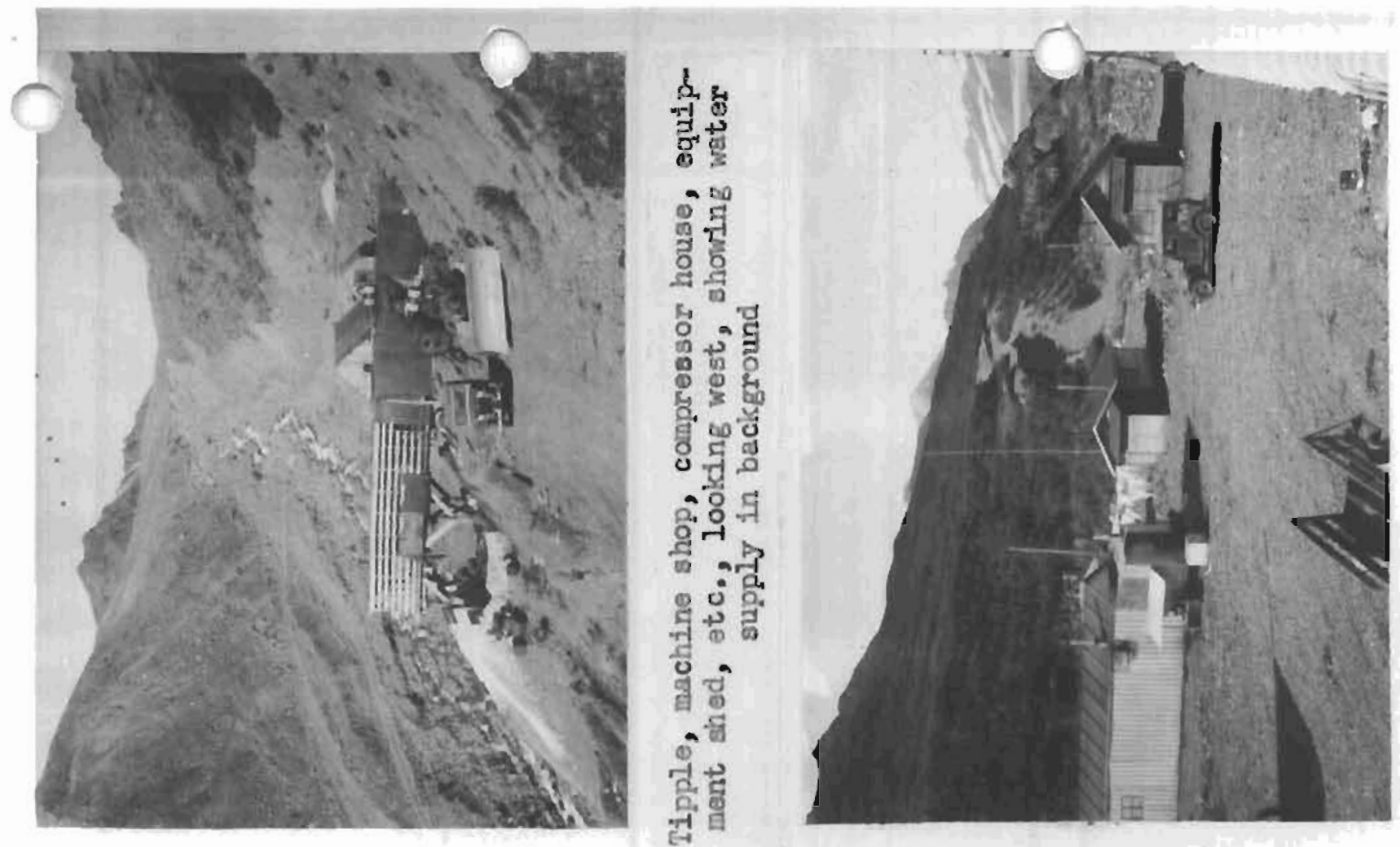

恕 迥

gु

वै की

मैं है

군

ल

- 8

त्ड \& के

है ज्ञ

व ब

兘 $0+$

견 핸

o 2 ह

ब 9

(2)

응

苗

궁

हैं क्ष
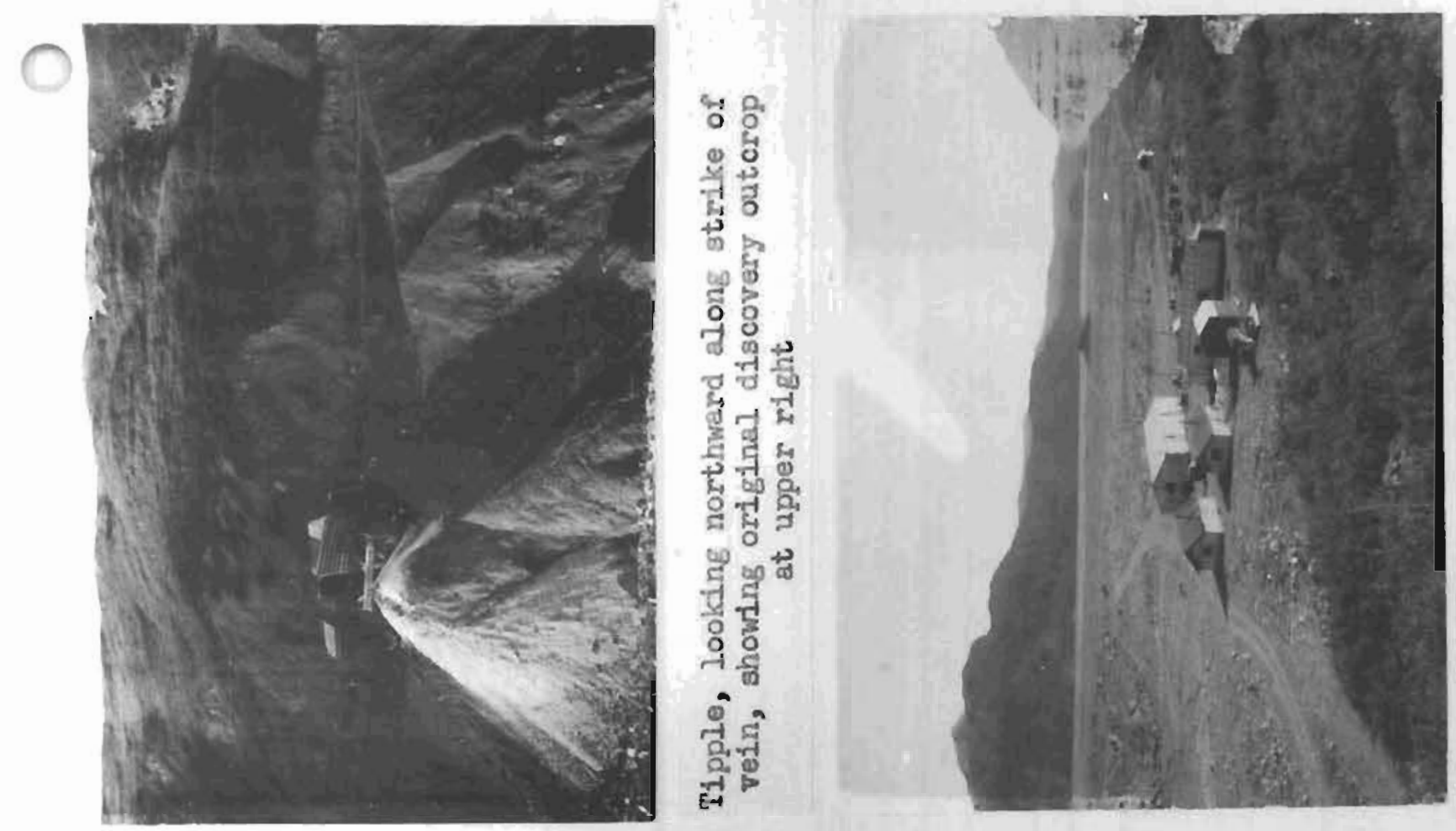

दै है

ํำ

담 + 규

a

कै क्षे

@ द

댁과 은

공 0 욜

8 के दो है

क्रे है 8 तै

d 3

음

a है हु

ถ⿻ㅇㅁ

들 욜

ने है है

नु है

옹 ऊू⿵ 